\title{
Bacteriophage Interactions with Marine Pathogenic Vibrios: Implications for Phage Therapy
}

\author{
Panos G. Kalatzis ${ }^{1,2}$ (D) , Daniel Castillo ${ }^{1}$, Pantelis Katharios ${ }^{2}$ (D) and Mathias Middelboe ${ }^{1, *}$ (1) \\ 1 Marine Biological Section, University of Copenhagen, DK-3000 Helsingør, Denmark; \\ panos.kalatzis@bio.ku.dk (P.G.K.); daniel.castillo@bio.ku.dk (D.C.) \\ 2 Institute of Marine Biology, Biotechnology and Aquaculture, Hellenic Centre for Marine Research, 71500 \\ Crete, Greece; katharios@hcmr.gr \\ * Correspondence: mmiddelboe@bio.ku.dk; Tel.: +45-3532-1991
}

Received: 1 February 2018; Accepted: 21 February 2018; Published: 24 February 2018

\begin{abstract}
A global distribution in marine, brackish, and freshwater ecosystems, in combination with high abundances and biomass, make vibrios key players in aquatic environments, as well as important pathogens for humans and marine animals. Incidents of Vibrio-associated diseases (vibriosis) in marine aquaculture are being increasingly reported on a global scale, due to the fast growth of the industry over the past few decades years. The administration of antibiotics has been the most commonly applied therapy used to control vibriosis outbreaks, giving rise to concerns about development and spreading of antibiotic-resistant bacteria in the environment. Hence, the idea of using lytic bacteriophages as therapeutic agents against bacterial diseases has been revived during the last years. Bacteriophage therapy constitutes a promising alternative not only for treatment, but also for prevention of vibriosis in aquaculture. However, several scientific and technological challenges still need further investigation before reliable, reproducible treatments with commercial potential are available for the aquaculture industry. The potential and the challenges of phage-based alternatives to antibiotic treatment of vibriosis are addressed in this review.
\end{abstract}

Keywords: marine vibrios; bacteriophages; phage therapy; biological control; aquaculture; interactions; vibriosis

\section{Vibrios in Marine Ecosystems}

The Vibrionaceae family, and more specifically, the genus Vibrio, encompasses genetically and metabolically diverse, heterotrophic bacteria that can thrive in a great range of habitats. The particularly versatile features of vibrios have made them ubiquitous components of world's marine and even brackish or freshwater ecosystems [1]. The relatively high abundance (often $10^{3}$ to $10^{4}$ cells per mL) and biomass of vibrios in the oceans [2], makes them important players in marine biogeochemical cycling. Key traits supporting this are (a) their ability to survive for a long time under nutrient-limited conditions [3,4], (b) their ability to maintain high ribosome content, which helps them achieve a fast recovery from starvation as soon as carbon sources become available [5-7], and c) their chemotactic response in finding nutrient sources [8-11].

The vast majority of vibrios occupy ecological niches associated with attachment to living organisms, which provide them protection and nutrients [12-14]. However, vibrios also occur as free-living cells in the water column $[15,16]$. Among several environmental variables that have been examined, salinity and temperature have been consistently linked to the observed variation in the total Vibrio abundance in the water column [17,18]. For example, $V$. vulnificus could tolerate a broad range in salinity from 5 to $38 \mathrm{ppt} \mathrm{[19],} \mathrm{while} V$. cholerae can grow in salinities of up to $45 \mathrm{ppt}$, if the nutrient concentration is high [20]. High temperature significantly boosts the growth of vibrios and 
the increased sea surface temperature has been suggested to promote a long-term increase in Vibrio abundance [21,22].

Their opportunistic lifestyle features, as well as their easy cultivation under laboratory conditions, have made them ideal models for investigations of bacterial population biology and genomics, disease dynamics, bacteria-phage interactions, and quorum sensing (QS) [23-26].

Several Vibrio species are pathogenic, and constitute a serious threat for human health. Over 80 species have been described, and at least 12 of them are known human pathogens [27,28]. V. cholerae, the causative agent of epidemic cholera, was introduced in Europe via sea trade routes from Asia, and was a devastating disease during 1817-1923 [29]. V. cholerae, as well as the seafood poisoning agents $V$. parahaemolyticus and V. vulnificus [30], have aroused significant attention among the scientific community, especially today, when increases in Vibrio-associated disease outbreaks in response to elevated ocean temperatures [31-33] emphasize the increasing importance of vibrio pathogens in a future warmer climate $[34,35]$.

\section{Vibrios in Aquaculture}

According to Food and Agriculture Organization (FAO) [36], aquaculture is one of the most rapidly growing sectors for animal food production, supporting approximately $50 \%$ of the global human fish consumption. Vibrios have been characterized as the "scourge" of marine fish and shellfish, since several members of the genus can be the causative agents of a fatal disease, commonly known as vibriosis [37]. Sudden vibriosis outbreaks have been causing severe losses in biomass, with significant economic consequences for the aquaculture industry [38]. Furthermore, lower growth rate of sick fish and shellfish, excessive waste of fish feeds, and finally, the increased skepticism of consumers about aquaculture's quality and credibility, are also important consequences of vibriosis.

Sustainability in aquaculture demands a thorough and sophisticated disease management plan in which the issue of pathogenic vibrios should be an integral part. The last report of the World Bank about prospects for fisheries and aquaculture [39] is a case in point, since it was reported that Vibrio-caused disease designated as early mortality syndrome (EMS), or else, acute hepatopancreatic necrosis disease (AHNPD), is a rapidly emerging disease, and a serious setback to the shrimp rearing industries of Asia and America [40,41]. FAO has drawn special attention to vibriosis [36], because the distribution of vibrios is being shifted according to the changing warming patterns, hence, outbreaks tend to be observed even in temperate or cold regions [42].

V. anguillarum, initially reported as Bacillus anguillarum [43], used to be the first isolated Vibrio to which "Red Pest of eels" was attributed, during early 1900s [44]. Although it still remains a serious threat for aquaculture $[45,46]$, a plethora of other Vibrio species have been recorded in the literature as causative agents of vibriosis in aquaculture. V. harveyi, V. parahaemolyticus, V. alginolyticus, V. vulnificus, and $V$. splendidus [28,47-52] are the most important, while the list is expanding with the discovery of new pathogenic species, such as $V$. owensii [53].

Chemical stressors, such as poor water quality and diet composition, biological stressors, such as population density and presence of other micro- or macro-organisms, and physical stressors, such as temperature above $15^{\circ} \mathrm{C}$, are the most important factors triggering vibriosis outbreaks $[46,54]$. Although the regulatory mechanisms of virulence in vibrios still need to be elucidated, virulence-related factors and genes that have been found in several pathogenic marine Vibrio. Iron uptake systems of $V$. ordalii, $V$. vulnificus, $V$. alginolyticus, and $V$. anguillarum have been recorded to contribute to their virulence, by binding the iron attached to the siderophore proteins of their hosts $[46,50,55]$. Extracellularly secreted proteins can have proteolytic, hydrolytic, hemolytic, and cytotoxic activity in several pathogenic Vibrio, such as V. anguillarum, V. alginolyticus, V. harveyi, V. splendidus, and $V$. pelagius [56-60]. However, the presence of virulence genes alone is not always a sufficient condition for a virulent phenotype. For instance, both virulent and avirulent $V$. harveyi and $V$. campbellii do carry virulence genes. It has been found that virulence can be coordinated via cell to cell communication, regulated by the presence of specific signal molecules [61]. The three-channel QS system of V. campbellii, 
previously described as $V$. harveyi [62], is a well-described case of QS-regulated virulence system using three different signals [63]. It was also recently shown that the virulence of $V$. anguillarum against European seabass (Dicentrarchus labrax) larvae is regulated by the indole signaling molecule pathway [64]. Clinical signs of vibriosis (Figure 1) include lethargic behavior, loss of appetite, unusual swimming behavior close to the water surface, increased mucus secretion, as well as petechiae and hemorrhages on their skin. Additional symptoms of the disease commonly observed are intestinal necrosis, anemia, ascetic fluid, petechial hemorrhages in the muscle wall, and liquid in the swim bladder $[65,66]$.

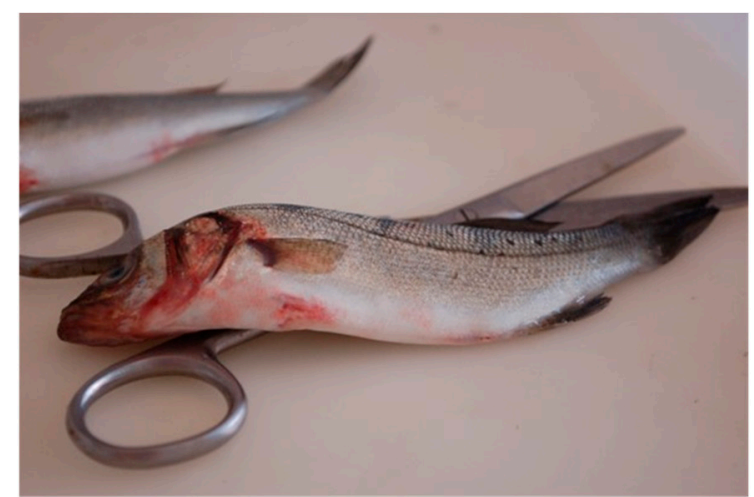

(a)

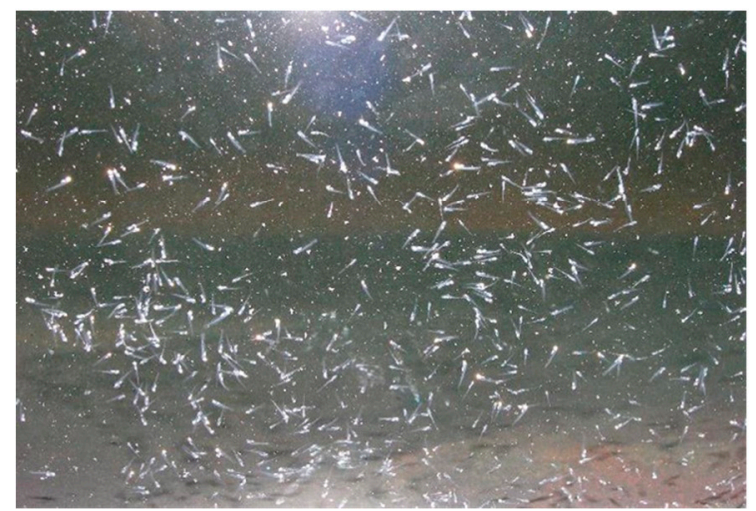

(c)

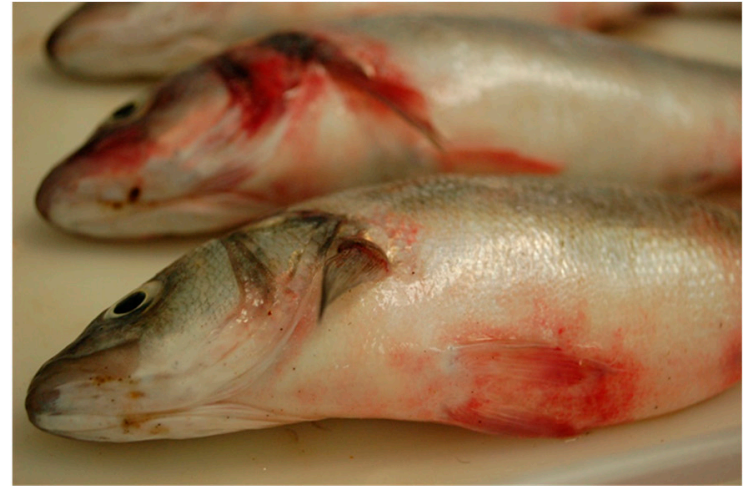

(b)

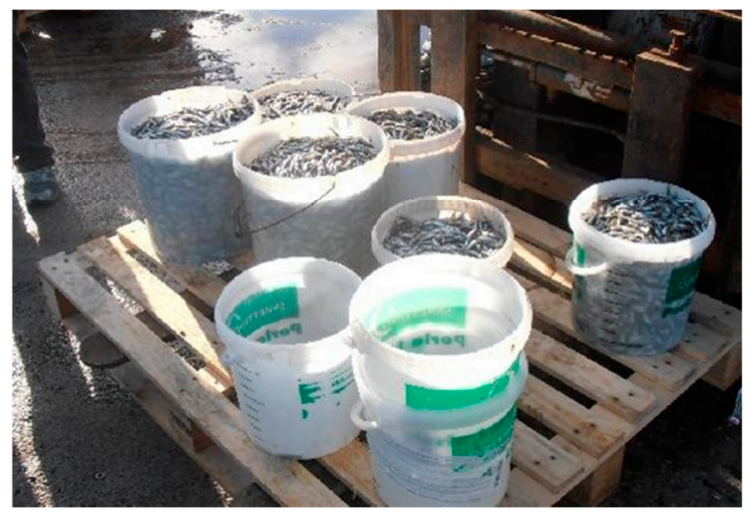

(d)

Figure 1. Massive mortalities caused by vibriosis in different developmental stages. $(\mathbf{a}, \mathbf{b})$ cultured European seabass, Dicentrarchus labrax, (c) cultured European seabass, Dicentrarchus labrax fry and (d) cultured gilthead sea bream, Sparus aurata larvae in the hatchery.

A vibriosis outbreak may have catastrophic consequences for both the cultured animals and the producer, hence, implementation of preventive strategies is the safest way to cope with such potential events. Development of vaccines against vibriosis has so far been quite successful, since it has managed to significantly prevent the outbreaks of the disease [67], yet there are still important issues to be addressed. While fish are still in the hatchery, their immune system is not completely developed yet, thus vaccination is inefficient at this stage. Additionally, vaccination of juvenile fish by injection is difficult, so they are vaccinated orally and/or by immersion, resulting in low efficacy and short protection [68]. However, this is not the case for all vibrios, since immersion vaccination against $V$. anguillarum has been shown to provide a high level of protection. The biggest problem, however, is the lack of commercially available vaccines for the majority of the pathogenic Vibrio species other than $V$. anguillarum. Administration of antibiotics is therefore the most commonly applied strategy to tackle vibriosis outbreaks. However, if applied in marine hatcheries, antibiotics disturb the natural microbial balance in the water, as well as the developing microbiota of the larvae [69]. Furthermore, the 
excessive amount of antibiotics that have been used, not only for treatment, but even for prophylaxis during the last decades, has become a constantly growing problem for human and animal health, as well as for the environment [70]. There is a fundamental difficulty in controlling the amount and types of antibiotics that are applied, since the regulations for their usage can vary broadly among different countries. Development of multi-drug resistant strains, disturbance of natural microbiota, environmental residues, and public health issues, are only some of the most important problems caused by the excessive use of chemotherapy [71], and new alternatives are necessary.

\section{Lytic Bacteriophages against Marine Vibrios}

The use of bacteriophages against pathogenic bacteria in aquaculture was first introduced experimentally in Japan against Lactococcus garvieae in 1999 [72], and it has since been a topic of great interest for the scientific community [73-76]. Vibrios have been one of the main targets for bacteriophage isolation because of their high pathogenicity, broad presence, and ability to infect cultured fish and shellfish at various culture stages. Several potent phages have been tested against vibriosis causative agents, such as $V$. harveyi, V. parahaemolyticus, V. alginolyticus, V. splendidus, $V$. anguillarum, and $V$. coralliilyticus (Table 1), leading, in all cases, to increased survival rates of the cultured animals.

Table 1. Phage therapy trials against causative agents of vibriosis in experimental aquaculture setups.

\begin{tabular}{ccc}
\hline Cultured Animal & Causative Agent & Reference \\
\hline Penaeus monodon & & {$[77-81]$} \\
Haliotis laevigata & V. harveyi & {$[82]$} \\
Panulirus ornatus & & {$[83]$} \\
Ostrea plicaltula & V. parahaemolyticus & {$[84]$} \\
Litopenaeus vannamei & V. alginolyticus & {$[85]$} \\
Apostichopus japonicus & V. splendidus & {$[86]$} \\
Apostichopus japonicus & V. cyclitrophicus & {$[88]$} \\
Apostichopus japonicas & V.anguillarum & {$[89]$} \\
Salmo salar & V. coralliilyticus & {$[90]$} \\
Danio rerio & & {$[91]$} \\
Acropora millepora &
\end{tabular}

Biological treatment of $V$. harveyi-caused vibriosis has been quite successful in Penaeus monodon shrimp hatcheries. Vinod and colleagues [77] performed both short-term and long-term phage treatment trials using a broad host range, lytic siphovirus. During the short-term trials $(48 \mathrm{~h})$, the lytic vibriophage was administered as phage suspension at low multiplicity of infection $(\mathrm{MOI}=1)$ to post-larval shrimps (18 days) that were previously infected by $V$. harveyi. Both single-dose $(0 \mathrm{~h})$ and double-dose $(0$ and $24 \mathrm{~h}$ ) phage administration, led to $70 \%$ shrimp survival along with a 2-log reduction of $V$. harveyi, and $80 \%$ shrimp survival along with a 3-log reduction of $V$. harveyi, respectively. By contrast, controls without phage treatment showed only $25 \%$ survival and a 1-log increase of $V$. harveyi. During long-term trials (17 days), 35,000 naturally $V$. harveyi-infected nauplii were treated with the lytic vibriophage on a daily basis, and their average survival was $86 \%$, compared to only $17 \%$ in the non-treated nauplii. Compared to antibiotics, which only led to a $40 \%$ survival, phage therapy provided better protection for infected shrimp. Similarly, Karunasagar and colleagues performed large-scale phage trials in a commercial shrimp hatchery using two lytic $V$. harveyi-specific broad host range bacteriophages. Phage application yielded $88 \%$ and $86 \%$ shrimp survival for each of the phages, while in antibiotic-treated (oxytetracycline and kanamycin) tanks, shrimp survival was $68 \%$ and $65 \%$, respectively [79].

Phage therapy applications have shown promising results in other commercial species, such as sea cucumber, Apostichopus japonicus [87]. Three lytic bacteriophages (PVS-1, PVS-2 and PVS-3) were in all cases effective when tested in vitro against four pathogenic V. splendidus strains. Focusing on the 
preventive aspect of phage therapy, the authors prepared six different diets: a non-supplemented diet serving as control, an antibiotic-supplemented, three diets supplemented with single phages, and a diet that was supplemented with a cocktail of the three phages. Juvenile sea cucumbers were then fed on a daily basis. After 60 days, the animals were challenged by immersion in seawater containing $V$. splendidus for 2 days, and their survival rates were monitored for 10 days. The survival was $18 \%$ for the control diet, $82 \%$ for the antibiotics-supplemented diet, $65 \%, 58 \%$, and $50 \%$ for the individual phage-supplemented diets and $82 \%$ for the phage cocktail-supplemented diet. In the same study, $V$. splendidus strain VS-ABTNL was injected in two groups of healthy sea cucumbers, while the control group was injected with sterile seawater. A phage cocktail was subsequently injected in one of the infected groups, and the survival rates were monitored for the following 10 days. All animals in the control group survived (100\%), only $20 \%$ in the non-treated group and $80 \%$ survived in the phage treated group. Thus, it was concluded that phage cocktails could successfully protect $A$. japonicus against $V$. splendidus infection, and that both injection and immersion worked as delivery routes of phages. $V$. splendidus is a rapidly emerging pathogen, and the attempts for isolation of lytic phages have attracted a keen interest lately [92]. Similar phage trials in A. japonicus cultures have been performed against $V$. alginolyticus and $V$. cyclitrophicus using a mixture of two vibriophages and one vibriophage, respectively. In the former case, phage treatment at MOI $=10$ led to $73 \%$ survival rates of the sea cucumbers, compared to only $3 \%$ survival that was observed in the non-treated group [86]. In the latter, the survival rate of juvenile $A$. japonicus was enhanced from $18 \%$ to $81 \%$ when fed with phage-containing feed, to $63 \%$ when injected with purified phage virions and to $58 \%$ when immersed in the phage-containing bath [88].

The bacteriophage CHOED has been tested for conferring protection against vibriosis in Atlantic salmon (Salmo salar) [89]. The presence of CHOED at MOI of 1 and 20 provided $100 \%$ protection of the fish against $V$. anguillarum, whereas untreated fish suffered over $90 \%$ mortality. When $S$. salar was challenged with $V$. anguillarum in aquaculture conditions, the administration of CHOED at MOI of 100 resulted in $100 \%$ fish survival 20 days after exposure to the pathogen, compared to only $60 \%$ survival in the non-treated fish.

The in vitro use of a phage cocktail with VP-1, VP-2, and VP-3 against V. parahaemolyticus, has been significantly more effective than using individual phages, albeit VP-3 was mainly responsible for the cocktail's lytic activity [93]. Although the efficacy of the phages contained in the cocktail can vary, multivalent phage cocktails can be effective against several pathogenic strains of the host and they can greatly delay the development of resistance due to the different phage components. Moreover, the idea of a phage cocktail allows the use of lytic phages with narrow host ranges, since several of them can be combined to produce a much broader lytic spectrum [94].

Phage delivery methods are of vital importance for a successful therapy, and depend on the presence of the phages at the area of infection in a titer above the therapeutic threshold. Ryan and colleagues have reviewed the phage delivery routes in human phage therapy trials, and they concluded that parenteral injection is the most successful route of phage administration, because the phages can immediately reach the systemic circulation [95]. In several aquaculture phage therapy trials, administration of bacteriophages via injection has also been the most successful route of delivery, since bacteriophages could be detected in the fish tissues for several days after administration $[76,96]$. However, parenteral injection, apart from the fact that it is rather stressful for the animals, has significant limitations in its practical application when (1) fish or shellfish are too small or too numerous or (2) continuous treatment is required. In the majority of the in vivo trials, phages are added to the water simultaneously, or right after the bacteria. This method reduces the number of pathogens used for the challenge, which in turn results in lower infection rate. The oral route of delivery, the immersion in phage bath, and the addition of phages to the surrounding water are very common methods that often lead to high protection against bacterial pathogens $[74,75,97]$ and greatly increase the applicability of phage therapy. Especially, administration of phages via phage-coated feed has been shown to be an efficient delivery method, resulting in constant, high abundance of phages in the fish 
organs for several weeks [97]. A variety, though, of delivery routes has been suggested in aquaculture phage trials, because bacterial infections can occur during all the developmental stages of cultured organisms; from the eggs to the broodstock [98].

Reducing the number of vibrios in aquaculture environment is another strategy that has been examined. Pathogenic vibrios are present in live feeds offered to fish or invertebrate larvae, and the feed is thus a major source of pathogens entering the marine hatcheries [93,99]. Preventive administration of bacteriophages can be applied either directly to the environment of the cultured animal, preferably during early growth stages, or to the live prey, to control the source of pathogens to the hatchery facilities. V. anguillarum, $V$. alginolyticus, and $V$. splendidus are some common examples of pathogenic vibrios which are entering the aquaculture environment through live feeds, such as Artemia salina and Brachionus plicatilis (Figure 2) [52,100-102].

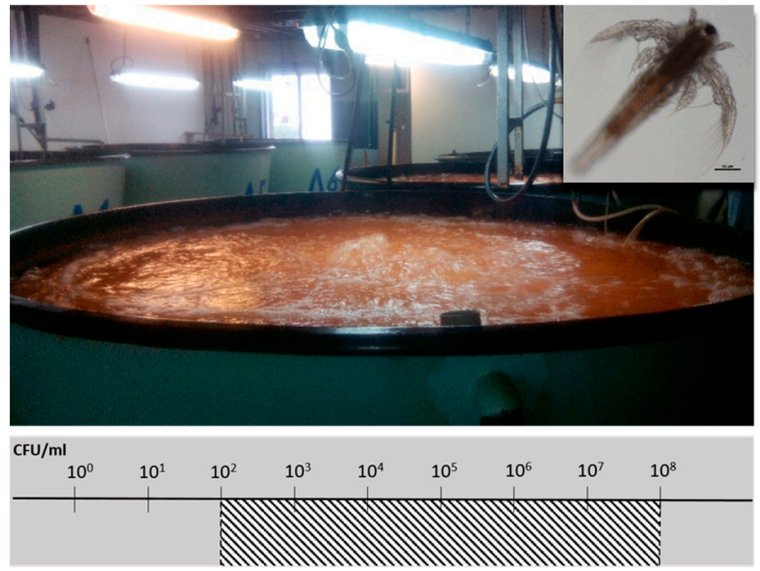

(a)

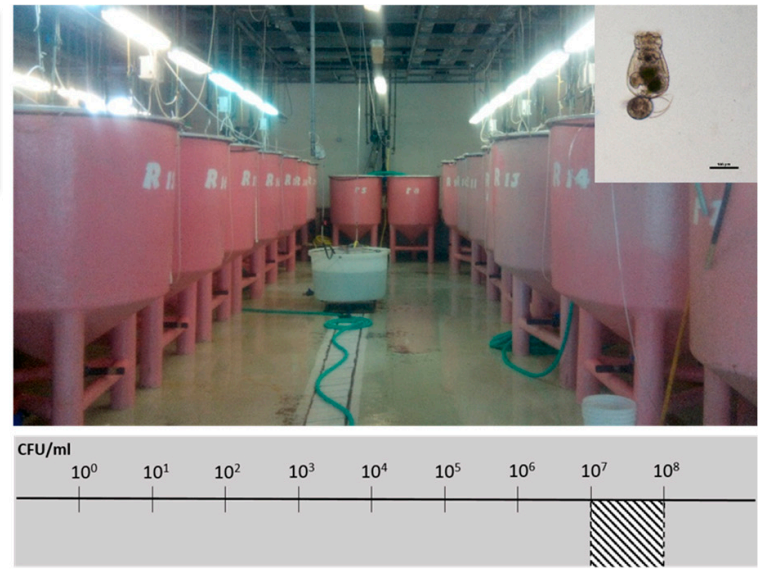

(b)

Figure 2. Facilities for live feed production from a commercial fish farm unit. (a) Artemia salina in culture tanks with vigorous aeration, where the native presumptive Vibrio load is regularly estimated between $10^{7}$ and $10^{8}$ cells per $\mathrm{mL}$; (b) Brachionus plicatilis culture tanks, where the native presumptive Vibrio load is regularly between $10^{2}$ and $10^{8}$ cells per mL [103].

The $V$. alginolyticus-specific broad host range lytic phages $\varphi$ St2 and $\varphi$ Grn1 have been successfully used as a "smart" disinfectant that selectively reduces vibrios in live feeds. Since V. alginolyticus is a prevalent component in live feeds, such as Artemia and rotifers, a scheme of precautionary phage administration in Artemia salina live feed cultures was evaluated. A combination of these two phages was administered in A. salina live prey at MOI: 100, leading to a significant reduction of the native Vibrio load by $1.3 \mathrm{log}$ units, suggesting a decrease in the risk of a vibriosis outbreak in the marine hatchery [104]. Further research on $\varphi \mathrm{St} 2$ and $\varphi \mathrm{Grn} 1$ has revealed that during infection, these phages are able to hijack and reprogram the host's metabolic machinery, in order to meet their augmented demands for energy and nucleotide biosynthesis, making their therapeutic potential highly efficient [105].

\section{The Profile of a Good Candidate: KVP40 Case}

Several issues are important when selecting safe and efficient candidates for phage therapy and next generation sequencing technology plays an important role in revealing the genomic composition and the lytic nature of viruses, which are main criteria in the selection process. The absence of genes related either to lysogeny or to any known toxins [106] confirmed the lytic nature of the vibriophage KVP40, making it a proper candidate for phage therapy trials against vibriosis. Phage KVP40 [106,107], is a myovirus classified in a group which has been designated as "schizoT4like" or "KVP40-like" [108]. It was isolated against a clinical $V$. parahaemolyticus strain, however, it has a broad host range, able to infect several other strains of eight different Vibrio species: V. alginolyticus, V. cholerae, V. parahaemolyticus, 
V. anguillarum, V. splendidus, V. mimicus, V. natriegens, and V. fluvialis [25,107]. The broad lytic spectrum and efficiency against several causative agents of vibriosis emphasizes the potential of KVP40 to control vibriosis in aquaculture settings.

The bacterial receptor that KVP40 recognizes in order to infect its hosts is the universal outer membrane protein K (OmpK), which is very common among Vibrio species [109]. Targeting a broadly distributed receptor is a key point when looking for a broad lytic spectrum bacteriophage; however, as it will be further discussed below, this can also result in the development of several defense strategies from the bacterial host in order to reduce the cost of resistance. In addition, KVP40 is a phage with a large genome ( $244,835 \mathrm{bp})$ able to take advantage of its host's metabolic machinery in order to maximize the efficiency of the infection, and thus, the overall impact of phage therapy. Lytic bacteriophages can manipulate and reprogram the host's metabolic machinery in order to support and facilitate their own DNA replication and protein synthesis, which are necessary for the packaging and release of the new virions $[110,111]$. They can mediate a transition from a host-oriented to a phage-oriented metabolism $[112,113]$ during infection, since the interactions of their early phage genes with DNA metabolism-involved host proteins, cease the host replication [110]. KVP40 was found to encode a functional $\mathrm{NAD}^{+}$salvage pathway, which can boost its own replication during infection. This pathway is also conserved in other large genome phages that carry similar genes involved in nucleotide metabolism [114]. Last but not least, many phages, including KVP40, carry a high number of tRNAs, which may provide the phage with a small degree of autonomy when it comes to the translation of its own genes [115].

\section{Issues Raised in Phage Therapy}

As evident from above, phage therapy is definitely an attractive alternative to combat pathogenic bacteria, which may be used not only as a treatment, but also to prevent infections. However, there are several important constraints, such as the phage efficacy under aquaculture conditions, administration methods and persistence of phages in the system, the possibility of unwanted phage-encoded properties and, perhaps most importantly, the development of phage resistance, that need to be evaluated before a phage therapy application scheme can be considered successful.

\subsection{Phage Therapy from the Lab to the Field}

During the stages of a therapeutic phage suspension development in the lab, host specificity, life cycle parameters and lytic nature of the phage, are the main prerequisites that need to be covered. The selection of appropriate phages that are going to be used alone or forming a phage cocktail is also crucial for the outcome of the phage therapy. However, despite the promising results that some lytic bacteriophages have shown under laboratory conditions, application of phage-based treatment in aquaculture settings is associated with a number of additional challenges that need to be addressed.

Previously, reporting of phages with low in vivo activity has been one reason for questioning globally the actual efficacy of phage therapy against bacterial infections in animals and humans [116,117]. The optimal phage delivery method (injection, oral, immersion) may vary between different aquaculture settings, and should be carefully determined in each case. For instance, although injection has been mentioned as the most effective delivery route [95], immersion of the cultured animals in phage-containing water has been also quite effective, since bacteria begin their infection cycle from adhering to the mucosa of the fish, which constitutes the first physical and chemical barrier of fish against pathogens [118]. Marine fish species drink water to maintain their internal ionic balance, and therefore, phages of the water will have the opportunity to encounter pathogenic bacteria for which the infection route is through the fish intestinal mucosa. Even when bacteria attack the intestinal mucosa, fish drink a lot of water, so phages still encounter intestinal bacteria [97]. In vitro results based on immersion are very often similar to those obtained in vivo, since this approach, in both cases, is based on phage-bacteria interactions that take place in a phage-containing suspension [119]. Quantification of the viruses, in the animal tissues or in the aquatic environment where therapy was applied, will define the efficacy of the 
delivery route. However, repeated phage administration using either delivery route has been the most effective way to maintain a high bacteriophage titer in the system $[77,87,97]$. Oral administration via phage-coated fish pellets is a quite feasible and effective way to keep a constant phage input to the system with minimum effort, and easily incorporated into the daily routine of the fish farm [97]. Furthermore, as the pathogens may be present in different stages of the production process, it is important to consider where in the production the addition of phages is expected to most efficiently reduce the pathogen (i.e., disinfection of live feed, disinfection of fish eggs, treatment of infected fish, etc.).

\subsection{Concerns about Phage-Treated Organisms}

A bacterial lysate might contain endotoxins which, if not removed, may be fatal for the cultured organism $[120,121]$. The phage stocks that are administered to the cultured organisms should therefore be meticulously prepared to remove bacterial debris, secondary metabolites, enzymes, etc., that might potentially be toxic for the fish or shellfish [122]. Endotoxin-free phage suspensions are regularly produced today $[123,124]$, eliminating potential side effects that may create unnecessary consideration to legislation and public opinion about phage therapy. Another concern about phage therapy in organisms such as fish, which have an adaptive immune system, is the potential immunological response of the phage-treated organism, that might trigger the production of phage-neutralizing antibodies, decreasing in vivo phage efficacy $[125,126]$. This possibility in aquaculture has been examined after phage-coated feed administered in yellowtail, Seriola lalandi [72] and intramuscular phage injection in ayu, Plecoglossus altivelis [127], however, phage-neutralizing antibodies were not detected in the studies. Production of such antibodies after phage administration in aquaculture is not yet documented in the literature [74].

\subsection{Development of Resistance}

Development of resistance is probably the most significant limitation in the whole concept of phage therapy. In the ocean, phages and their bacterial hosts are in a perpetual arms race, under strong evolutionary pressure [128,129]. Although the use of phage cocktails can reduce or delay the emergence of resistant strains $[93,130]$, bacteria have developed several strategies (Figure 3) to cope with their viral predators [131-133].

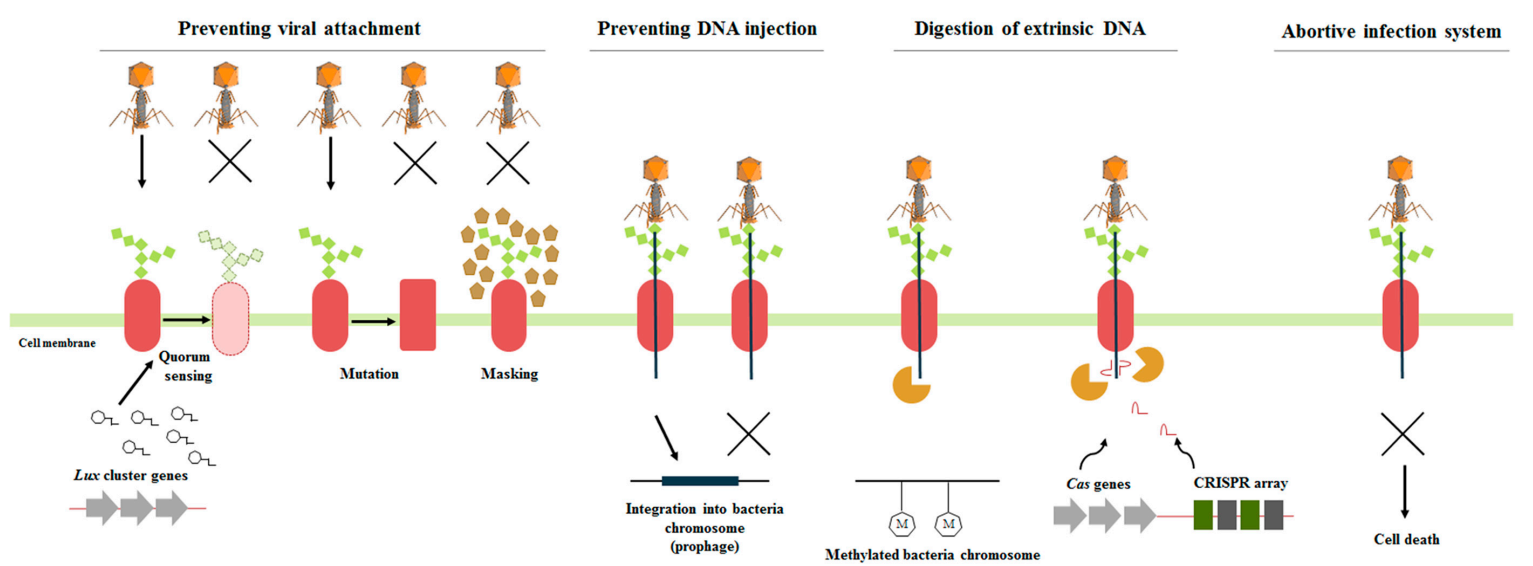

Figure 3. Overview of the main phage defense mechanisms in bacteria. Prevention of viral attachment on the bacterial surface can be achieved by mutating or masking the receptors, as well as downregulation of receptor expression, orchestrated by quorum sensing (QS). DNA injection may be successfully averted by superinfection exclusion (Sie) mechanisms. If phage DNA enters the bacterial host, its digestion can be catalyzed by R-M mechanism and CRISPR-Cas arrays systems. Deliberate death of the infected cell (abortive infection) constitutes another strategy against viral predators, where prevention of phage proliferation reduces spreading of the infection to the rest of the population. 


\subsubsection{Preventing Viral Attachment}

The most crucial step for the successful infection of a bacterial host by a phage is its adsorption by the host through a specific reaction between the phage receptor-binding protein and the bacterial cell surface receptor. There is a great variety of components on the bacterial surfaces that are targets for phage attachment, such as proteins, polysaccharides, and lipopolysaccharides [134]. However, bacteria have developed strategies to effectively prevent phage adsorption events by (a) modifying the phage receptors by mutational changes, (b) masking receptors by producing an extracellular matrix, (c) producing competitive inhibitors, or (d) losing or downregulating the expression of the receptor [131,133]. In several cases the regulation of surface modifications is orchestrated by QS [135]. For instance, in the case of KVP40 phage infecting V. anguillarum, QS is used by bacteria in order to select between two different protection mechanisms according to their population density. At low host densities, the OmpK receptor for KVP40 is fully expressed, and the bacteria are protected from infection by forming aggregates and biofilms. At high host densities, the OmpK receptor is downregulated through a QS regulation pathway, making $V$. anguillarum less susceptible to the phage [24]. In V. cholerae, a different mechanism has been described, where surface modification of the phage receptor prevents attachment of the lytic phage ICP2 [136]. However, bacteriophages can regain their ability to attach on their targets by modifying their receptor-binding proteins and getting access to the modified bacterial cell surface receptors [137].

\subsubsection{Preventing DNA injection}

Even if the adsorption of the phage has been successful, bacteria have developed strategies to prevent the injection of the incoming viral DNA. Superinfection exclusion (Sie) systems are based on proteins related to cell surface modifications or inhibition of replication, and are often encoded by prophages or plasmids. Sie systems can provide immunity to the prophage-carrying bacterium against a second potential infection by similar bacteriophages [133,138,139]. A subcategory of Sie is the repressor-mediated immunity, where the repressor protein retains the prophage in the lysogenic cycle while providing immunity against an infective phage carrying the same type of repressor [140]. In a recent study, several temperate $V$. anguillarum-specific bacteriophages, designated as H20-like phages, were shown to contain a lambda-like cI repressor gene in their genomes. It was suggested that this mechanism possibly confers repressor-mediated immunity to other H20-like phages in their V. anguillarum host [141]. A Sie system-encoding prophage has recently been reported to confer phage resistance in the V. cholerae strain 919TP [142]. Compared to receptor alteration strategies, which prevent phage adsorption, and thus only protect the individual resistant cell, the Sie systems immobilize and inactivate the phage, thereby reducing the infection load on the remaining population [143].

\subsubsection{Digesting Extrinsic DNA}

In cases where the phage DNA enters the bacterial host, bacteria have developed several mechanisms for its inactivation: (a) Restriction-modification (R-M) systems and (b) CRISPR-Cas system [131]. R-M systems (type I, II, III, and IV) are composed by a methyltransferase and a restriction endonuclease, which catalyze the methylation of the bacterial DNA and the cleavage of the viral, unmethylated DNA, respectively [144-146]. Almost all bacterial genera carry R-M systems [133], and it is hypothesized that high levels of horizontal gene transfer (HGT) are responsible for their spreading and evolution among prokaryotes [145]. Vibriophage KVP40 has been reported to be restricted and modified by the R-M system of at least five Vibrio species [147]. However, phages have simultaneously evolved to evade the omnipresent R-M systems. Approximately, $20 \%$ of the available phage genomes carry methyltransferase-encoding genes, suggesting the ability to protect their own genome through methylation [141,148]. Methyltransferases can also affect bacterial virulence [149] or they may function as transcriptional regulators by either activating or repressing bacterial genes [150,151]. N6-adenine methyltransferase was previously found in the temperate vibriophage VHML, where it was linked 
to the virulence of $V$. harveyi host strain upon integration [152]. H20-like vibriophages were also found to carry a N6-adenine methyltransferase gene; however, its exact function still needs to be explored [141]. Phages may methylate parts of their genome, preventing its degradation by the host's restriction enzymes, whereas methylation could modify the properties of the host. It has been reported that viral infection of specific bacterial hosts subsequently affected the host range of the newly produced virions $[153,154]$, suggesting that specific differences in the methylation of viral DNA during phage production affects the infectivity of the produced phages. Integrating conjugative elements (ICEs), ICEVspPor3 and ICEValSpa1, that were recently identified in V. splendidus and V. alginolyticus, respectively, harbor genes encoding distinct R-M systems, which are able to confer protection against viral infection when expressed in Escherichia coli [155].

CRISPR-Cas has been described as an adaptive immune system of bacteria. This system is composed of (1) cas genes, which are responsible for the expression of the protein machinery that performs the immune response, and (2) the CRISPR loci, composed of 21-48 bp direct repeats interspaced by non-repetitive spacers of 26-72 bp, which provide genetic memory of previous viral infections. Although there are two classes, six types, and 16 subtypes of CRISPR-Cas systems [156], all of them are based on three common functional phases: (1) adaptation-spacer(s) from invasive DNA are acquired and then integrated into the CRISPR loci of the bacterial genome, (2) expression-transcription of the CRISPR loci that encode a CRISPR RNA (crRNA) molecule which will be combined with Cas protein forming crRNA-Cas complexes, and (3) interference-the crRNA-Cas complexes attach and digest complementary nucleic acids, providing immunity to the bacterial host [131]. Among the sequenced bacterial genomes, CRISPR loci are found in approximately $40 \%$ of them [157]. Although CRISPR-Cas systems are highly sophisticated, their conferred immunity can be bypassed by the bacteriophages by mutations or deletions in the targeted proto-spacer in the phage genome. Single nucleotide mutations in the protospacer genomic region of $S$. thermophilus phages were able to circumvent their bacterial host's CRISPR-Cas defense system [158,159]. Screening of the 1935 publicly available Vibrio genomes using CRISPRfinder [160] showed that CRISPR(s) were present in 278 (14.4\%) genomes. Most of the CRISPR-containing Vibrio strains had one CRISPR array, but some carried up to 11 [161]. In total, 388 CRISPR arrays were identified in all the Vibrio genomes The CRISPR prevalence in the Vibrio genus is thus substantially lower than the reported $50 \%$ in bacteria in general [156]. Within the 28 genomesequenced V. anguillarum strains, only one strain, V. anguillarum PF7, contained CRISPR. Out of the two CRISPR-Cas arrays of $V$. anguillarum PF7, eighteen spacers were $>95 \%$ similar to genomic parts of the H20-like vibriophages, with eight of them being 100\% identical [141]. The knowledge of the contribution of CRISPR-Cas systems in vibrios' defense is sporadic, and needs to be more thoroughly evaluated. It is also worth mentioning that the $V$. cholerae phage ICP1 is the first bacteriophage recorded to encode its own CRISPR-Cas arrays as a counter-defense against $V$. cholerae phage inhibitory chromosomal island [162].

\subsubsection{Abortive Infection System}

Bacterial infection by phages can sometimes be non-productive, even though it leads to the death of bacterial host. This kind of abortive infection may be the result of "lysis from without" (LO), where extensive simultaneous infections (i.e., very high MOI) may destroy the cell membrane. In another type of abortive infection leading to non-productive phage infections, the infected bacteria can enter a programmed cell death, and thereby prevent the spreading of the infection to the neighboring cells. This altruistic behavior is orchestrated by the abortive infection (Abi) system [131,163]. Although the best characterized Abi system is the Rex system, which is found in phage $\lambda$-lysogenized E. coli preventing infection by other coliphages [164,165], and most Abis have been identified in plasmids of Gram-positive strains [163], V. cholerae has also been documented as a carrier of such a system [166]. However, it has been proven that some Abis, such as TA system ToxIN described in Pectobacterium atrosepticum, may act also through toxin-antitoxin (TA) mechanisms, aborting phage infection [167]. TAs were initially found in plasmids, but are now known to be abundant in bacterial 
genomes. The components of these systems, a toxin and an antitoxin, neutralize each other, keeping the balance that maintains bacterial life. Upon phage infection, toxin and antitoxin production stops, yet antitoxin degrades faster, allowing the toxin to kill the bacterial cell [168]. For instance, MosAT TA system in $V$. cholerae resembles AbiE, a broadly distributed TA-Abi system in bacterial genomes inducing bacteriostasis and conferring phage resistance [168]. A high number of both confirmed and putative TA systems have been reported in V. cholerae and V. parahaemolyticus $[169,170]$, however, their potential functionality as Abi systems still needs to be elucidated.

Even though the result of abortive infections is lysis of the bacterial cell, the phenomenon limits self-adjusting properties of the phages because there is no virion production. The implication of this defense mechanism in vibrios needs to be evaluated in vitro, during the assessment of the viral lytic spectrum.

\subsubsection{Resistance Comes at a Cost}

Thinking of the variety of phage defense mechanisms identified in bacteria, one might wonder what determines their distribution among bacteria, and why not all bacteria carry all of them. The explanation is that development of resistance comes at a fitness cost for the bacteria [171], so they need to be parsimonious when they invest on resistance strategies. Phage-binding bacterial receptors, which serve as recognition points for the phages, are often also associated with important cell functions, such as nutrient uptake, motility, and ability to attach on surfaces [172-174]. Therefore, surface modifications may significantly reduce bacterial fitness, including a reduced colonization ability $[175,176]$ and increased susceptibility to other phages [177]. Loss of virulence and gliding motility has been observed in phage resistant Flavobacterium columnare [178], and similar results were recorded in phage-resistant Flavobacterium psychrophilum strains, which have shown decreased hemolytic activity, gelatinase activity, and total protease activity, as well as mutations in significant virulence genes [179]. Accordingly, in vibrios, phage-resistant strains have been shown to be less harmful against their eukaryotic host. In experimentally challenged pipefish (Syngnathus typhle), three Vibrio spp. Isolates, representing different phage susceptibility, showed positive correlation between phage susceptibility and virulence [180]. Further, loss of virulence was observed in four KVP40-resistant V. anguillarum strains as demonstrated by reduced mortality of cod (Gadus morhua) larvae challenged with phage-resistant clones, compared to a control group challenged with the wild type V. anguillarum strain [181].

Bacteria and phages are in a perpetual arms race, so phages also evolve counter-defensive strategies to circumvent bacterial defense mechanisms. The fitness cost, including loss of virulence, which is often associated with resistance, constitutes a barrier to the prevalence of these defense mechanisms [131], and selection pressure on different anti-phage strategies depends on the trade-off between mortality imposed by phages and fitness cost of the defense strategy, under the given environmental conditions. Hence, constitutive defense strategies, such as mutating the bacterial receptors and inducible defense strategies, such as CRISPR-Cas systems, may prevail under different conditions and for different phage-host interactions. In the former case, modification of the receptors is permanently associated with a substantial fixed cost that directly affects bacterial fitness, while in the latter case, bacterial CRISPR-Cas systems may be elicited only upon viral infection [182]. The force of infection and the nutrient availability are usually the most important factors that will determine the bacterial decision between constitutive and inducible defense mechanisms [182-184]. The CRISPR-Cas system is favored when the frequency of infection is low and the nutrients are limited, because it is associated with a lower cost for the bacterial cell. Viruses can, though, quickly mutate and escape, suggesting that these systems would be most effective when exposed to low phage diversity, due to relatively limited capacity for spacer acquisition. Accordingly, genomic mapping of CRISPR spacers and viral genomes has shown that only recently acquired resistance was functional for phage defense [185]. On the other hand, surface modifications are favored when frequency of infection is high and nutrients are abundant, because bacteria need to be in an "always on" defensive position, even if the costs are high [182]. 
Acquiring resistance against more than one bacteriophage might increase the fitness cost for the host, since it will need to modify different phage-binding surface receptors $[175,186]$. Therefore, coping with phage cocktails implies a higher fitness cost for the bacteria. Furthermore, the accumulating indications that phage-resistance leads to dominance of less virulent phenotypes, suggest that the problems with resistance associated with phage treatment in aquaculture may be limited. Indeed, the fitness cost of phage immunity needs to be comprehensively explored, with special emphasis on the virulence properties of phage resistant pathogens, potentially allowing the prediction of the implications of the development of presumably less virulent phage resistant bacteria for the survival of phage treated animals.

\section{Temperate Vibriophages and Lysogenic Conversion}

Another concern when selecting phages for therapeutic purposes is the risk of using phages encoding unwanted genes that may spread in the pathogen population. Consequently, it must be explicit that only lytic bacteriophages should be considered as potential candidates.

However, temperate bacteriophages are also a vital part of the natural virome, and key players in driving bacterial evolution by disseminating genetic information through horizontal gene transfer (HGT). HGT may take place in both lytic and temperate phage with the form of generalized transduction, whereas the events of specialized transduction and lysogenic conversion are restricted only to temperate phages $[187,188]$. The high rate of generalized transduction events, which also applies to lytic phages, has lately raised significant concerns against phage therapy, since virulence or resistance genetic element might spread among the pathogenic bacteria [189]. Complementary researches on E. coli and Streptococcus pyogenes, though, have shown that antibiotic resistance genes may be disseminated only through temperate transducing bacteriophages [190-192]. However, it was recently found that two lytic bacteriophages against E. coli, designated as "superspreaders", could promote extensive plasmid transformation, and therefore efficiently disperse antibiotic resistance genes [193]. Hence, it is crucial that such phages are avoided in phage therapy or other medical applications.

A serious constraint in phage therapy is, therefore, the unsafe use of temperate phages as therapeutic agents. The process through which prophages integrate in their host's genome and transfer genes whose expression may render increased bacterial fitness, either directly (e.g., phage-encoded toxins) or indirectly (e.g., increased fitness during infection) is designated as lysogenic conversion. This process possesses a dominant role in conferring enhanced fitness to the prophage-carrying bacteria. The importance of this process is highlighted in vibrios, since there is a plethora of vibriophages where lysogenic conversion has positively affected, both directly and indirectly, the fitness of their lysogenized hosts. A classic example of lysogenic conversion in vibrios is the phage-mediated production of cholera toxin, by the filamentous phage $C T X \Phi$ [194]. However, there are several examples of lysogenic conversion in other Vibrio pathogens. V. harveyi strains carrying the prophage VHML, were able to metabolize fewer nutrient sources than their uninfected counterparts [195]. Switching off unnecessary bacterial functions would make lysogenized $V$. harveyi strains less energy-consuming, hence more competitive under nutrient-limited environments [196]. The same temperate phage VHML was reported as being responsible for conferring virulence to the $V$. harveyi strain 642 , since avirulent $V$. harveyi strains were converted to virulent, when infected by phage VHML [78,197]. A similar observation was made in the case of the prophage VOB, which was integrated in the genome of its $V$. owensii host. After the induction of $\mathrm{VOB}$ in the lab, it was co-cultured with naïve $V$. harveyi and $V$. campbellii. The avirulent vibrios were lysogenized by the induced VOB and they became virulent, causing increased mortality to Penaeus monodon. It was concluded that VOB was responsible for some of the virulence of $V$. owensii, as well as for the acquired virulence of $V$. harveyi and $V$. campbellii lysogens [198]. In a very recent study, prophage-like elements that were identified in the genomes of V. anguillarum strains T265 and Ba35, contained genes related to zonula occludens toxin (Zot), implying the contribution of the prophage to bacterial virulence [199]. Prophages K139 and VIPФ have also 
been reported to increase the pathogenesis of their $V$. cholerae hosts by increasing both virulence and colonization ability $[200,201]$. Lysogenic conversion may be implicated also in bacterial host's defense against viral infection. Phage-induced lysis of some cells could release prophage-encoded toxins, such as colicins, that might eliminate competitors, helping the rest of the bacterial population to take advantage of the environmental niche and resources [202,203]. In a recently published study, the tail length tape measure gene that was identified in the genome of the H20-like temperate vibriophages resembled the structure of channel forming toxin colicin Ia, hence, an additional role of the gene in bacterial competition was suggested by the authors [141]. Furthermore, Sie and Abi defense systems that were previously mentioned, are also among the beneficial effects that prophages impart to their hosts [204].

Although temperate bacteriophages are not suitable for therapeutic purposes, lysogenic lifestyle is the symbiotic aspect of the virus-bacteria interactions which has been the outcome of their refined co-evolutionary relationships [205]. Already in 1961, Campbell suggested a beneficiary contribution of prophages to their host by stating "One therefore must look for possible means by which the phage might impart a selective advantage to its host" [206].

\section{Perspectives on Phage Therapy Today}

Wherever bacteria thrive, so do predatory phages. During 2017, we celebrated 100 years from the discovery of the bacteriophages and the idea of using specific bacteriophages as a weapon to biologically control pathogenic bacteria. Phage therapy approaches against bacterial infections have been revived, primarily due to major problems with antibiotic-resistant bacteria we are facing as a result of excessive usage of antibiotics. In addition, the increasing temperature in the oceans, the fatal effects of vibriosis on the global aquaculture industry, as well as a plethora of different vibrios that may trigger the disease has further emphasized the need for exploring the potential of phages to control vibrio pathogens.

While the initial idea behind phage therapy was treatment of diseases, as in the case of antibiotics, future work should include prophylactic use of lytic bacteriophages to reduce the pathogen load and reduce the risk of infection. In marine aquaculture, addition of bacteriophages to live feeds, such as Artemia and rotifers, may be an efficient way to selectively disinfect the life feeds immediately prior to entering fish or invertebrate production cycle. Since both Artemia and rotifers are produced in batch cultures with a short retention time, the risk of resistance development is minimal, as opposed to providing phages prophylactically in the feeds of fish, or directly in rearing tanks, which would allow for phage-bacteria co-evolution. However, application of lytic phages as fish feed additives may be an efficient way to prevent the pathogens from establishing in the fish organs. Recirculating aquaculture systems (RAS) could be ideal environments for the application of phage therapy, since the water exchange is quite limited. Additionally, the combinatory usage of bacteriophages, together with another ecologically friendly alternative such as probiotic bacteria, constitutes a strategy that would be expected to be highly effective against bacterial diseases. Combining biological approaches with different targets and modes of action may minimize the risk of future resistance development, as has been seen in human medicine, where combined drugs are successful in antibacterial and antiviral treatment.

More research is still required to optimize the phage application under field conditions (phage composition, timing of application, delivery etc.) and to eliminate the potential risk factors associated with phage application (dispersal of unwanted genes, effects on fish microbiota). Further investigation of the naturally occurring phages in the cultured animals' microbiota is going to unravel their role in the organism's protection against bacterial diseases, and evaluate the possibility of them being used in a more targeted phage therapy scheme. This requires extensive sequencing of viral genomes and analyses for presence of genetic elements that might potentially interfere with the bacterial fitness or affect the organism's health. Such knowledge would also provide us a window for visualizing a future of molecularly engineered lytic virions. Consequently, more in vitro and in vivo test trials are 
required before the final release, and any side effects need to be meticulously recorded. However, facing a future with increasing problems with antibiotic resistant pathogens, exploring phage-based alternatives is now more necessary than ever.

Acknowledgments: The study was supported by the Danish Council for Strategic Research (ProAqua project 12-132390), The Danish Council for Independent Research (DFF-7014-00080), and by the Greek National Strategic Reference Framework 2007-2013 (co-funded by European Social Fund and Greek National Funds) FISHPHAGE project 131, www.gsrt.gr. We would like to thank Panos Varvarigos, DVM and Nancy Dourala, DVM for their contribution in Figure 1c,d and Figure 2a,b.

Author Contributions: Panos G. Kalatzis collected, analyzed, interpreted the data and drafted the manuscript. Daniel Castillo designed Figure 3. Daniel Castillo, Pantelis Katharios and Mathias Middelboe interpreted the data and revised the manuscript. All authors read and approved the manuscript.

Conflicts of Interest: The authors declare no conflict of interest.

\section{References}

1. Thompson, F.L.; Iida, T.; Swings, J. Biodiversity of vibrios. Microbiol. Mol. Biol. Rev. 2004, 403-431. [CrossRef] [PubMed]

2. Yooseph, S.; Nealson, K.H.; Rusch, D.B.; McCrow, J.P.; Dupont, C.L.; Kim, M.; Johnson, J.; Montgomery, R.; Ferriera, S.; Beeson, K.; et al. Genomic and functional adaptation in surface ocean planktonic prokaryotes. Nature 2010, 468, 60-66. [CrossRef] [PubMed]

3. Ramaiah, N.; Ravel, J.; Straube, W.L.; Hill, R.T.; Colwell, R.R. Entry of Vibrio harveyi and Vibrio fischeri into the viable but nonculturable state. J. Appl. Microbiol. 2002, 93, 108-116. [CrossRef] [PubMed]

4. Armada, S.P.; Farto, R.; Pérez, M.J.; Nieto, T.P. Effect of temperature, salinity and nutrient content on the survival responses of Vibrio splendidus biotype I. Microbiology 2003, 149, 369-375. [CrossRef] [PubMed]

5. Flardh, K.; Cohen, P.S.; Kjelleberg, S. Ribosomes exist in large excess over the apparent demand for protein synthesis during carbon starvation in marine Vibrio sp. strain CCUG 15956. J. Bacteriol. 1992, 174, 6780-6788. [CrossRef] [PubMed]

6. Kramer, J.G.; Singleton, F.L. Variations in rRNA content of marine Vibrio spp. during starvation- survival and recovery. Appl. Environ. Microbiol. 1992, 58, 201-207. [PubMed]

7. Eilers, H.; Pernthaler, J.; Amann, R. Succession of pelagic marine bacteria during enrichment: A close look at cultivation-induced shifts. Appl. Environ. Microbiol. 2000, 66, 4634-4640. [CrossRef] [PubMed]

8. Yu, C.; Bassler, B.L.; Roseman, S. Chemotaxis of the marine bacterium Vibrio furnissii to sugars. A potential mechanism for initiating the chitin catabolic cascade. J. Biol. Chem. 1993, 268, 9405-9409. [PubMed]

9. Gosink, K.K.; Kobayashi, R.; Kawagishi, I.; Häse, C.C. Analyses of the roles of the three cheA homologs in chemotaxis of Vibrio cholerae. J. Bacteriol. 2002, 184, 1767-1771. [CrossRef] [PubMed]

10. Larsen, M.H.; Blackburn, N.; Larsen, J.L.; Olsen, J.E. Influences of temperature, salinity and starvation on the motility and chemotactic response of Vibrio anguillarum. Microbiology 2004, 150, 1283-1290. [CrossRef] [PubMed]

11. Grimes, D.J.; Johnson, C.N.; Dillon, K.S.; Flowers, A.R.; Noriea, N.F.; Berutti, T. What genomic sequence information has revealed about Vibrio ecology in the ocean-a review. Microb. Ecol. 2009, 58, 447-460. [CrossRef] [PubMed]

12. Andrews, J.H.; Harris, R.F. The ecology and biogeography of microorganisms on plant surfaces. Annu. Rev. Phytopathol. 2000, 145-180. [CrossRef] [PubMed]

13. Simidu, U.; Ashino, K.; Kaneko, E. Bacterial flora of phyto- and zoo- plankton in the inshore water of Japan. Can. J. Microbiol. 1971, 19, 1157-1160. [CrossRef]

14. Hollants, J.; Leliaert, F.; De Clerck, O.; Willems, A. What we can learn from sushi: A review on seaweedbacterial associations. FEMS Microbiol. Ecol. 2013, 83, 1-16. [CrossRef] [PubMed]

15. Froelich, B.; Ayrapetyan, M.; Oliver, J.D. Integration of Vibrio vulnificus into marine aggregates and its subsequent uptake by Crassostrea virginica oysters. Appl. Environ. Microbiol. 2013, 79, 1454-1458. [CrossRef] [PubMed]

16. Lyons, M.M.; Lau, Y.T.; Carden, W.E.; Ward, J.E.; Roberts, S.B.; Smolowitz, R.; Vallino, J.; Allam, B. Characteristics of marine aggregates in shallow-water ecosystems: Implications for disease ecology. Ecohealth 2007, 4, 406-420. [CrossRef] 
17. Takemura, A.F.; Chien, D.M.; Polz, M.F. Associations and dynamics of Vibrionaceae in the environment, from the genus to the population level. Front. Microbiol. 2014, 5, 1-26. [CrossRef] [PubMed]

18. Thompson, J.R.; Randa, M.A.; Marcelino, L.A.; Tomita-Mitchell, A.; Lim, E.; Polz, M.F. Diversity and dynamics of a north atlantic coastal Vibrio community. Appl. Environ. Microbiol 2004, 70, 4103-4110. [CrossRef] [PubMed]

19. Kaspar, C.W.; Tamplin, M.L. Effects of temperature and salinity on the survival of Vibrio vulnificus in seawater and shellfish. Appl. Environ. Microbiol. 1993, 59, 2425-2429. [PubMed]

20. Singleton, F.L.; Attwell, R.; Jangi, S.; Colwell, R.R. Effects of temperature and salinity on Vibrio cholerae growth. Appl. Environ. Microbiol. 1982, 44, 1047-1058. [PubMed]

21. Vezzulli, L.; Grande, C.; Reid, P.C.; Hélaouët, P.; Edwards, M.; Höfle, M.G.; Brettar, I.; Colwell, R.R.; Pruzzo, C. Climate influence on Vibrio and associated human diseases during the past half-century in the coastal North Atlantic. Proc. Natl. Acad. Sci. USA 2016, 113, E5062-E5071. [CrossRef] [PubMed]

22. Vezzulli, L.; Höfle, M.; Pruzzo, C.; Pezzati, E.; Brettar, I. Effects of global warming on Vibrio ecology. Microbiol. Spectr. 2015, 3. [CrossRef] [PubMed]

23. Letchumanan, V.; Pusparajah, P.; Tan, L.T.H.; Yin, W.F.; Lee, L.H.; Chan, K.G. Occurrence and antibiotic resistance of Vibrio parahaemolyticus from shellfish in Selangor, Malaysia. Front. Microbiol. 2015, 6, 1-11. [CrossRef] [PubMed]

24. Tan, D.; Svenningsen, S.L.; Middelboe, M. Quorum sensing determines the choice of antiphage defense strategy in Vibrio anguillarum. mBio 2015, 6, 1-10. [CrossRef] [PubMed]

25. Tan, D.; Gram, L.; Middelboe, M. Vibriophages and their interactions with the fish pathogen Vibrio anguillarum. Appl. Environ. Microbiol. 2014, 80, 3128-3140. [CrossRef] [PubMed]

26. Le Roux, F.; Wegner, K.M.; Polz, M.F. Oysters and vibrios as a model for disease dynamics in wild animals. Trends Microbiol. 2016, 24, 568-580. [CrossRef] [PubMed]

27. Oliver, J.; Pruzzo, C.; Vezzulli, L.; Kaper, J. Vibrio species. In Food Microbiology: Fundamentals and Frontiers; Doyele, M., Buchanan, R., Eds.; ASM Press: Washington, WA, USA, 2013; pp. 401-440.

28. Plaza, N.; Castillo, D.; Pérez-Reytor, D.; Higuera, G.; García, K.; Bastías, R. Bacteriophages in the control of pathogenic vibrios. Electron. J. Biotechnol. 2018, 31, 24-33. [CrossRef]

29. Epstein, P.R. Algal blooms in the spread and persistence of cholera. BioSystems 1993, 31, 209-221. [CrossRef]

30. Thompson, J.R.; Marcelino, L.; Polz, M.F. Diversity, sources and detection of human bacterial pathogens in the marine environment. In Oceans and Health: Pathogens in the Marine Environment; Springer: New York, NY, USA, 2005; pp. 29-69. ISBN 0-387-23709-7.

31. Kimes, N.E.; Grim, C.J.; Johnson, W.R.; Hasan, N.A.; Tall, B.D.; Kothary, M.H.; Kiss, H.; Munk, A.C.; Tapia, R.; Green, L.; et al. Temperature regulation of virulence factors in the pathogen Vibrio coralliilyticus. ISME J. 2012, 6, 835-846. [CrossRef] [PubMed]

32. Vezzulli, L.; Brettar, I.; Pezzati, E.; Reid, P.C.; Colwell, R.R.; Höfle, M.G.; Pruzzo, C. Long-term effects of ocean warming on the prokaryotic community: Evidence from the vibrios. ISME J. 2012, 6, 21-30. [CrossRef] [PubMed]

33. Baker-Austin, C.; Trinanes, J.A.; Taylor, N.G.H.; Hartnell, R.; Siitonen, A.; Martinez-Urtaza, J. Emerging Vibrio risk at high latitudes in response to ocean warming. Nat. Clim. Chang. 2013, 3, 73-77. [CrossRef]

34. Lipp, E.K.; Huq, A.; Colwell, R.R. Effects of global climate on infectious disease: The cholera model. Clin. Microbiol. Rev. 2002, 15, 757-770. [CrossRef] [PubMed]

35. Froelich, B.A.; Noble, R.T. Vibrio bacteria in raw oysters: Managing risks to human health. Philos. Trans. R. Soc. Lond. B Biol. Sci. 2016, 371. [CrossRef] [PubMed]

36. Food and Agriculture Organization of the United Nations. The State of World Fisheries and AquacultureContributing to Food Security and Nutrition for All; FAO Report; FAO: Rome, Italy, 2016; ISBN 9789251091852.

37. Austiin, B.; Austin, D.A. Vibrionaceae representatives. In Bacterial Fish Pathogens, Disease of Frmed and Wild Fish; Springer: Dordrecht, The Netherlands, 2012; pp. 369-389, ISBN 978-94-007-4884-2.

38. Toranzo, A.E.; Magariños, B.; Romalde, J.L. A review of the main bacterial fish diseases in mariculture systems. Aquaculture 2005, 246, 37-61. [CrossRef]

39. The World Bank. Fish to 2030: Prospects for fisheries and aquaculture. Agric. Environ. Serv. Discuss. Pap. 2013, 3, 102.

40. De Schryver, P.; Defoirdt, T.; Sorgeloos, P. Early mortality syndrome outbreaks: A microbial management issue in shrimp farming? PLoS Pathog. 2014, 10, 10-11. [CrossRef] [PubMed] 
41. Zorriehzahra, M.J.; Banaederakhshan, R. Early Mortality Syndrome (EMS) as new emerging threat in shrimp industry. Adv. Anim. Vet. Sci. 2015, 2309-2331. [CrossRef]

42. Rowley, A.F.; Cross, M.E.; Culloty, S.C.; Lynch, S.A.; Mackenzie, C.L.; Morgan, E.; O’Riordan, R.M.; Robins, P.E.; Smith, A.L.; Thrupp, T.J.; et al. The potential impact of climate change on the infectious diseases of commercially important shellfish populations in the Irish Sea-A review. ICES J. Mar. Sci. 2014, 71, 741-759. [CrossRef]

43. Canestrini, G. La malatti dominate delle anguille. Atti Inst. Veneto Serv. 1893, 7, 809-814.

44. Bergman, A.M. Die rote Beulenkrankheit des Aals. Bericht aus der Königlichen Bayer. Versuchsstation 1909, 2, $10-54$.

45. Rønneseth, A.; Castillo, D.; D’Alvise, P.; Tønnesen, Ø.; Haugland, G.; Grotkjaer, T.; Engell-Sørensen, K.; Nørremark, L.; Bergh, Ø.; Wergeland, H.I.; et al. Comparative assessment of Vibrio virulence in marine fish larvae. J. Fish Dis. 2017. [CrossRef] [PubMed]

46. Frans, I.; Michiels, C.W.; Bossier, P.; Willems, K.A.; Lievens, B.; Rediers, H. Vibrio anguillarum as a fish pathogen: Virulence factors, diagnosis and prevention. J. Fish Dis. 2011, 34, 643-661. [CrossRef] [PubMed]

47. Austin, B.; Zhang, X.H. Vibrio harveyi: A significant pathogen of marine vertebrates and invertebrates. Lett. Appl. Microbiol. 2006, 43, 119-124. [CrossRef] [PubMed]

48. Wang, R.; Zhong, Y.; Gu, X.; Yuan, J.; Saeed, A.F.; Wang, S. The pathogenesis, detection, and prevention of Vibrio parahaemolyticus. Front. Microbiol. 2015, 6, 1-13. [CrossRef] [PubMed]

49. Zorilla, I.; Chabrillon, M.; Arijo, S.; Diaz-Rozales, P.; Martinez-Manzanares, E.; Balebona, M.C.; Morinigo, M.A. Bacteria recovered from diseased cultured gilthead sea bream (Sparus aurata L.) in southwestern Spain. Aquaculture 2003, 218, 11-20. [CrossRef]

50. Balebona, M.C.; Andreu, M.J.; Bordas, M.A.; Zorrilla, I.; Moriñigo, M.A.; Borrego, J.J. Pathogenicity of Vibrio alginolyticus for cultured gilt-head sea bream (Sparus aurata L.). Appl. Environ. Microbiol. 1998, 64, 4269-4275. [PubMed]

51. Fouz, B.; Amaro, C. Isolation of a new serovar of Vibrio vulnificus pathogenic for eels cultured in freshwater farms. Aquaculture 2003, 217, 677-682. [CrossRef]

52. Thomson, R.; Macpherson, H.L.; Riaza, A.; Birkbeck, T.H. Vibrio splendidus biotype 1 as a cause of mortalities in hatchery-reared larval turbot, Scophthalmus maximus (L.). J. Appl. Microbiol. 2005, 99, 243-250. [CrossRef] [PubMed]

53. Cano-Gómez, A.; Goulden, E.F.; Owens, L.; Høj, L. Vibrio owensii sp. nov., isolated from cultured crustaceans in Australia. FEMS Microbiol. Lett. 2010, 302, 175-181. [CrossRef] [PubMed]

54. Austin, B.; Austin, D.A. Bacterial Fish Pathogens: Diseases of Farmed and Wild Fish, 4th ed.; Springer-Praxis Publishing: New York, NY, USA, 2007.

55. Biosca, E.G.; Amaro, C. Toxic and enzymatic activities of Vibrio vulnificus biotype 2 with respect to host specificity. Appl. Environ. Microbiol. 1996, 62, 2331-2337. [PubMed]

56. Zhang, X.-H.; Austin, B. Pathogenicity of Vibrio harveyi to salmonids. J. Fish Dis. 2000, 23, 93-102. [CrossRef]

57. Binesse, J.; Delsert, C.; Saulnier, D.; Champomier-Vergès, M.C.; Zagorec, M.; Munier-Lehmann, H.; Mazel, D.; Le Roux, F. Metalloprotease Vsm is the major determinant of toxicity for extracellular products of Vibrio splendidus. Appl. Environ. Microbiol. 2008, 74, 7108-7117. [CrossRef] [PubMed]

58. Gómez-León, J.; Villamil, L.; Lemos, M.L.; Novoa, B.; Figueras, A. Isolation of Vibrio alginolyticus and Vibrio splendidus from aquacultured carpet shell clam (Ruditapes decussatus) larvae associated with mass mortalities. Appl. Environ. Microbiol. 2005, 71, 98-104. [CrossRef] [PubMed]

59. Kanemori, Y.; Nakai, T.; Muroga, K. The Role of Extracellular Protease Produced by Vibrio anguillarum. Fish Pathol. 1987, 22, 153-158. [CrossRef]

60. Farto, R.; Pérez, M.J.; Fernández-Briera, A.; Nieto, T.P. Purification and partial characterisation of a fish lethal extracellular protease from Vibrio pelagius. Vet. Microbiol. 2002, 89, 181-194. [CrossRef]

61. Defoirdt, T. Virulence mechanisms of bacterial aquaculture pathogens and antivirulence therapy for aquaculture. Rev. Aquac. 2014, 6, 100-114. [CrossRef]

62. Lin, B.; Wang, Z.; Malanoski, A.P.; O'Grady, E.A.; Wimpee, C.F.; Vuddhakul, V.; Alves, N.; Thompson, F.L.; Gomez-Gil, B.; Vora, G.J. Comparative genomic analyses identify the Vibrio harveyi genome sequenced strains BAA-1116 and HY01 as Vibrio campbellii. Environ. Microbiol. Rep. 2010, 2, 81-89. [CrossRef] [PubMed] 
63. Darshanee Ruwandeepika, H.A.; Sanjeewa Prasad Jayaweera, T.; Paban Bhowmick, P.; Karunasagar, I.; Bossier, P.; Defoirdt, T. Pathogenesis, virulence factors and virulence regulation of vibrios belonging to the harveyi clade. Rev. Aquac. 2012, 4, 59-74. [CrossRef]

64. Li, X.; Yang, Q.; Dierckens, K.; Milton, D.L.; Defoirdt, T. RpoS and indole signaling control the virulence of Vibrio anguillarum towards gnotobiotic sea bass (Dicentrarchus labrax) larvae. PLoS ONE 2014, 9, 1-7. [CrossRef] [PubMed]

65. Soumya Haldar, S.C. Vibrio related diseases in aquaculture and development of rapid and accurate identification methods. J. Mar. Sci. Res. Dev. 2012, s1. [CrossRef]

66. Diggles, B.K.; Carson, J.; Hine, P.M.; Hickman, R.W.; Tait, M.J. Vibrio species associated with mortalities in hatchery-reared turbot (Colistium nudipinnis) and brill (C. guntheri) in New Zealand. Aquaculture 2000, 183, 1-12. [CrossRef]

67. Colquhoun, D.J.; Lillehaug, A. Vaccination against vibriosis. In Fish Vaccination; John Wiley \& Sons, Ltd.: Chichester, UK, 2014; pp. 172-184, ISBN 9781118806913.

68. Embregts, C.W.E.; Forlenza, M. Oral vaccination of fish: Lessons from humans and veterinary species. Dev. Comp. Immunol. 2016, 64, 118-137. [CrossRef] [PubMed]

69. Olafsen, J.A. Interactions between fish larvae and bacteria in marine aquaculture. Aquaculture 2001, 200, 223-247. [CrossRef]

70. Cabello, F.C. Heavy use of prophylactic antibiotics in aquaculture: A growing problem for human and animal health and for the environment. Environ. Microbiol. 2006, 8, 1137-1144. [CrossRef] [PubMed]

71. Perreten, V. Resistance in the food chain and in bacteria from animals: Relevance to human infections. In Frontiers in Antimicrobial Resistance; White, D., Alekshun, M., McDermott, P., Eds.; American Society for Microbiology: Washington, DC, USA, 2005; pp. 446-464.

72. Nakai, T.; Sugimoto, R.; Park, K.H.; Matsuoka, S.; Mori, K.; Nishioka, T.; Maruyama, K. Protective effects of bacteriophage on experimental Lactococcus garvieae infection in yellowtail. Dis. Aquat. Organ. 1999, 37, $33-41$. [CrossRef] [PubMed]

73. Defoirdt, T.; Sorgeloos, P.; Bossier, P. Alternatives to antibiotics for the control of bacterial disease in aquaculture. Curr. Opin. Microbiol. 2011, 14, 251-258. [CrossRef] [PubMed]

74. Oliveira, J.; Castilho, F.; Cunha, A.; Pereira, M.J. Bacteriophage therapy as a bacterial control strategy in aquaculture. Aquac. Int. 2012, 20, 879-910. [CrossRef]

75. Richards, G.P. Bacteriophage remediation of bacterial pathogens in aquaculture: A review of the technology. Bacteriophage 2014, 4, e975540. [CrossRef] [PubMed]

76. Nakai, T.; Park, S.C. Bacteriophage therapy of infectious diseases in aquaculture. Res. Microbiol. 2002, 153, 13-18. [CrossRef]

77. Vinod, M.G.; Shivu, M.M.; Umesha, K.R.; Rajeeva, B.C.; Krohne, G.; Karunasagar, I.; Karunasagar, I. Isolation of Vibrio harveyi bacteriophage with a potential for biocontrol of luminous vibriosis in hatchery environments. Aquaculture 2006, 255, 117-124. [CrossRef]

78. Oakey, H.J.; Owens, L. A new bacteriophage, VHML, isolated from a toxin-producing strain of Vibrio harveyi in tropical Australia. J. Appl. Microbiol. 2000, 89, 702-709. [CrossRef] [PubMed]

79. Karunasagar, I.; Shivu, M.M.; Girisha, S.K.; Krohne, G.; Karunasagar, I. Biocontrol of pathogens in shrimp hatcheries using bacteriophages. Aquaculture 2007, 268, 288-292. [CrossRef]

80. Phumkhachorn, P.; Rattanachaikunsopon, P. Isolation and partial characterization of a bacteriophage infecting the shrimp pathogen Vibrio harveyi. Afr. J. Microbiol. 2010, 4, 1794-1800.

81. Stalin, N.; Srinivasan, P. Efficacy of potential phage cocktails against Vibrio harveyi and closely related Vibrio species isolated from shrimp aquaculture environment in the south east coast of India. Vet. Microbiol. 2017, 207, 83-96. [CrossRef] [PubMed]

82. Wang, Y.; Barton, M.; Elliott, L.; Li, X.; Abraham, S.; Dea, M.O.; Munro, J. Bacteriophage therapy for the control of Vibrio harveyi in greenlip abalone (Haliotis laevigata). Aquaculture 2017, 473, 251-258. [CrossRef]

83. Crothers-Stomps, C.; Høj, L.; Bourne, D.G.; Hall, M.R.; Owens, L. Isolation of lytic bacteriophage against Vibrio harveyi. J. Appl. Microbiol. 2010, 108, 1744-1750. [CrossRef] [PubMed]

84. Rong, R.; Lin, H.; Wang, J.; Khan, M.N.; Li, M. Reductions of Vibrio parahaemolyticus in oysters after bacteriophage application during depuration. Aquaculture 2014, 418-419, 171-176. [CrossRef]

85. Lomelí-Ortega, C.O.; Martínez-Díaz, S.F. Phage therapy against Vibrio parahaemolyticus infection in the whiteleg shrimp (Litopenaeus vannamei) larvae. Aquaculture 2014, 434, 208-211. [CrossRef] 
86. Zhang, J.; Cao, Z.; Li, Z.; Wang, L.; Li, H.; Wu, F.; Jin, L.; Li, X.; Li, S.; Xu, Y. Effect of bacteriophages on Vibrio alginolyticus infection in the sea cucumber, Apostichopus japonicus (Selenka). J. World Aquac. Soc. 2015, 46, 149-158. [CrossRef]

87. Li, Z.; Li, X.; Zhang, J.; Wang, X.; Wang, L.; Cao, Z.; Xu, Y. Use of phages to control Vibrio splendidus infection in the juvenile sea cucumber Apostichopus japonicus. Fish Shellfish Immunol. 2016, 54, 302-311. [CrossRef] [PubMed]

88. Li, Z.; Zhang, J.; Li, X.; Wang, X.; Cao, Z.; Wang, L.; Xu, Y. Efficiency of a bacteriophage in controlling Vibrio infection in the juvenile sea cucumber Apostichopus japonicus. Aquaculture 2016, 451, 345-352. [CrossRef]

89. Higuera, G.; Bastías, R.; Tsertsvadze, G.; Romero, J.; Espejo, R.T. Recently discovered Vibrio anguillarum phages can protect against experimentally induced vibriosis in Atlantic salmon, Salmo salar. Aquaculture 2013, 392-395, 128-133. [CrossRef]

90. Silva, Y.J.; Costa, L.; Pereira, C.; Mateus, C.; Cunha, A.; Calado, R.; Gomes, N.C.M.; Pardo, M.A.; Hernandez, I.; Almeida, A. Phage therapy as an approach to prevent Vibrio anguillarum infections in fish larvae production. PLoS ONE 2014, 9, e114197. [CrossRef] [PubMed]

91. Cohen, Y.; Joseph Pollock, F.; Rosenberg, E.; Bourne, D.G. Phage therapy treatment of the coral pathogen Vibrio coralliilyticus. Microbiologyopen 2013, 2, 64-74. [CrossRef] [PubMed]

92. Katharios, P.; Kalatzis, P.G.; Kokkari, C.; Sarropoulou, E.; Middelboe, M. Isolation and characterization of a N4-like lytic bacteriophage infecting Vibrio splendidus, a pathogen of fish and bivalves. PLoS ONE 2017, 12, e0190083. [CrossRef] [PubMed]

93. Mateus, L.; Costa, L.; Silva, Y.J.; Pereira, C.; Cunha, A.; Almeida, A. Efficiency of phage cocktails in the inactivation of Vibrio in aquaculture. Aquaculture 2014, 424-425, 167-173. [CrossRef]

94. Doss, J.; Culbertson, K.; Hahn, D.; Camacho, J.; Barekzi, N. A review of phage therapy against bacterial pathogens of aquatic and terrestrial organisms. Viruses 2017. [CrossRef] [PubMed]

95. Ryan, E.M.; Gorman, S.P.; Donnelly, R.F.; Gilmore, B.F. Recent advances in bacteriophage therapy: How delivery routes, formulation, concentration and timing influence the success of phage therapy. J. Pharm. Pharmacol. 2011, 63, 1253-1264. [CrossRef] [PubMed]

96. Madsen, L.; Bertelsen, S.K.; Dalsgaard, I.; Middelboe, M. Dispersal and survival of Flavobacterium psychrophilum phages in vivo in rainbow trout and in vitro under laboratory conditions: Implications for their use in phage therapy. Appl. Environ. Microbiol. 2013, 79, 4853-4861. [CrossRef] [PubMed]

97. Christiansen, R.H.; Dalsgaard, I.; Middelboe, M.; Lauritsen, A.H.; Madsen, L. Detection and quantification of Flavobacterium psychrophilum-specific bacteriophages in vivo in rainbow trout upon oral administration: Implications for disease control in aquaculture. Appl. Environ. Microbiol. 2014, 80, 7683-7693. [CrossRef] [PubMed]

98. Nakai, T. Application of bacteriophages for control of infectious diseases in aquaculture. In Bacteriophages in the Control of Food- and Waterborne Pathogens; Sabour, P.M., Griffiths, M.W., Eds.; American Society for Microbiology Press: Washington, DC, USA, 2010; pp. 257-272.

99. Sharma, S.; Chatterjee, S.; Datta, S.; Prasad, R.; Dubey, D.; Prasad, R.K.; Vairale, M.G. Bacteriophages and its applications: An overview. Folia Microbiol. (Praha) 2017, 62, 17-55. [CrossRef] [PubMed]

100. Prol-García, M.J.; Planas, M.; Pintado, J. Different colonization and residence time of Listonella anguillarum and Vibrio splendidus in the rotifer Brachionus plicatilis determined by real-time PCR and DGGE. Aquaculture 2010, 302, 26-35. [CrossRef]

101. Snoussi, M.; Chaieb, K.; Mahmoud, R.; Bakhrouf, A. Quantitative study, identification and antibiotics sensitivity of some Vibrionaceae associated to a marine fish hatchery. Ann. Microbiol. 2006, 56, $289-293$. [CrossRef]

102. Høj, L.; Bourne, D.G.; Hall, M.R. Localization, abundance and community structure of bacteria associated with Artemia: Effects of nauplii enrichment and antimicrobial treatment. Aquaculture 2009, 293, $278-285$. [CrossRef]

103. Dourala, N.; (Fish Health Manager, Selonda S.A., Greece). Personal communication, 2018.

104. Kalatzis, P.G.; Bastías, R.; Kokkari, C.; Katharios, P. Isolation and characterization of two lytic bacteriophages, $\varphi \mathrm{St} 2$ and $\varphi \mathrm{Grn} 1$; phage therapy application for biological control of Vibrio alginolyticus in aquaculture live feeds. PLoS ONE 2016, e0151101. [CrossRef] [PubMed] 
105. Skliros, D.; Kalatzis, P.G.; Katharios, P.; Flemetakis, E. Comparative functional genomic analysis of two Vibrio phages reveals complex metabolic interactions with the host cell. Front. Microbiol 2016, 7, 1-13. [CrossRef] [PubMed]

106. Miller, E.S.; Heidelberg, J.F.; Eisen, J.A.; Nelson, W.C.; Durkin, A.S.; Ciecko, A.; Feldblyum, T.V.; White, O.; Paulsen, I.T.; Nierman, W.C.; et al. Complete genome sequence of the broad host-range vibriophage KVP40: Comparative genomics of a T4-related bacteriophage. J. Bacteriol. 2003, 185, 5220-5233. [CrossRef] [PubMed]

107. Matsuzaki, S.; Tanaka, S.; Koga, T.; Kawata, T.A. Broad host-range vibriophage, KVP40, isolated from sea water. Microbiol. Immunol. 1992, 36, 93-97. [CrossRef] [PubMed]

108. Lavigne, R.; Darius, P.; Summer, E.J.; Seto, D.; Mahadevan, P.; Nilsson, A.S.; Ackermann, H.W.; Kropinski, A.M. Classification of Myoviridae bacteriophages using protein sequence similarity. BMC Microbiol. 2009, 9, 224. [CrossRef] [PubMed]

109. Inoue, T.; Matsuzaki, S.; Tanaka, S. A 26-kDa outer membrane protein, OmpK, common to Vibrio species is the receptor for a broad-host-range vibriophage, KVP40. FEMS Microbiol. Lett. 1995, 125, 101-105. [CrossRef] [PubMed]

110. Drulis-Kawa, Z.; Majkowska-Skrobek, G.; Maciejewska, B.; Delattre, A.-S.; Lavigne, R. Learning from bacteriophages-advantages and limitations of phage and phage-encoded protein applications. Curr. Protein Pept. Sci. 2012, 13, 699-722. [CrossRef] [PubMed]

111. Chevallereau, A.; Blasdel, B.G.; De Smet, J.; Monot, M.; Zimmermann, M.; Kogadeeva, M.; Sauer, U.; Jorth, P.; Whiteley, M.; Debarbieux, L.; Lavigne, R. Next-Generation "-omics" approaches reveal a massive alteration of host RNA metabolism during bacteriophage infection of Pseudomonas aeruginosa. PLoS Genet. 2016, 12, 1-20. [CrossRef] [PubMed]

112. Roucourt, B.; Lavigne, R. The role of interactions between phage and bacterial proteins within the infected cell: A diverse and puzzling interactome. Environ. Microbiol. 2009, 11, 2789-2805. [CrossRef] [PubMed]

113. Miller, E.S.; Kutter, E.; Mosig, G.; Kunisawa, T.; Rüger, W.; Arisaka, F.; Ru, W. Bacteriophage T4 genome. Microbiol. Mol. Biol. Rev. 2003, 67, 86-156. [CrossRef] [PubMed]

114. Lee, J.Y.; Li, Z.; Miller, E.S. Vibrio phage KVP40 encodes a functional NAD ${ }^{+}$salvage pathway. J. Bacteriol. 2017, 199, 1-18. [CrossRef] [PubMed]

115. Bailly-Bechet, M.; Vergassola, M.; Rocha, E. Causes for the intriguing presence of tRNAs in phages. Genome Res. 2007, 17, 1486-1495. [CrossRef] [PubMed]

116. Smith, H.W.; Huggins, M.B. Successful treatment of experimental Escherichia coli infections in mice using phage; its general superiority over antibiotics. J. Gen. Microbiol. 1982, 128, 307-318. [CrossRef] [PubMed]

117. Barrow, P.A.; Soothill, J.S. Bacteriophage therapy and prophylaxis: Rediscovery and renewed assessment of potential. Trends Microbiol. 1997, 5, 268-271. [CrossRef]

118. Shephard, K.L. Functions for fish mucus. Rev. Fish Biol. Fish. 1994, 4, 401-429. [CrossRef]

119. Summers, W.C. Bacteriophage therapy. Annu. Rev. Microbiol. 2001, 437-451. [CrossRef] [PubMed]

120. Gorbet, M.B.; Sefton, M.V. Endotoxin: The uninvited guest. Biomaterials 2005, 26, 6811-6817. [CrossRef] [PubMed]

121. Opal, S.M. Endotoxins and other sepsis triggers. Endotoxemia Endotoxin Shock Dis. Diagnosis Ther. 2010, 167, 14-24. [CrossRef]

122. Boratyński, J.; Syper, D.; Weber-Dąbrowska, B.; Łusiak-Szelachowska, M.; Poźniak, G.; Górski, A. Preparation of endotoxin-free bacteriophages. Cell. Mol. Biol. Lett. 2004, 9, 253-259. [PubMed]

123. Cooper, C.J.; Denyer, S.P.; Maillard, J.Y. Stability and purity of a bacteriophage cocktail preparation for nebulizer delivery. Lett. Appl. Microbiol. 2014, 58, 118-122. [CrossRef] [PubMed]

124. Szermer-Olearnik, B.; Boratyński, J. Removal of endotoxins from bacteriophage preparations by extraction with organic solvents. PLoS ONE 2015, 10, e0122672. [CrossRef] [PubMed]

125. Pirisi, A. Phage therapy-advantages over antibiotics? Lancet 2000, 356, 1418. [CrossRef]

126. Sulakvelidze, A.; Alavidze, Z.; Morris, J.G. Bacteriophage therapy. Antimicrob. Agents Chemother. 2001, 45, 649-659. [CrossRef] [PubMed]

127. Park, S.C.; Nakai, T. Bacteriophage control of Pseudomonas plecoglossicida infection in ayu Plecoglossus altivelis. Dis. Aquat. Organ. 2003, 53, 33-39. [CrossRef] [PubMed]

128. Suttle, C.A. Viruses in the sea. Nature 2005, 437, 356-361. [CrossRef] [PubMed]

129. Samson, J.E.; Magadán, A.H.; Sabri, M.; Moineau, S. Revenge of the phages: Defeating bacterial defences. Nat. Rev. Microbiol. 2013, 11, 675-687. [CrossRef] [PubMed] 
130. Chan, B.K.; Abedon, S.T.; Loc-carrillo, C. Phage cocktails and the future of phage therapy. Future Microbiol. 2013, 769-783. [CrossRef] [PubMed]

131. Houte, S. van; Buckling, A.; Westra, E.R. Evolutionary ecology of prokaryotic immune mechanisms. Microbiol. Mol. Biol. Rev. 2016, 80, 745-763. [CrossRef] [PubMed]

132. Westra, E.R.; Swarts, D.C.; Staals, R.H.J.; Jore, M.M.; Brouns, S.J.J.; van der Oost, J. The CRISPRs, they are A-Changin': How prokaryotes generate adaptive immunity. Annu. Rev. Genet. 2012, 46, 311-339. [CrossRef] [PubMed]

133. Labrie, S.J.; Samson, J.E.; Moineau, S. Bacteriophage resistance mechanisms. Nat. Rev. Microbiol. 2010, 8 , 317-327. [CrossRef] [PubMed]

134. Rakhuba, D.V.; Kolomiets, E.I.; Szwajcer Dey, E.; Novik, G.I. Bacteriophage receptors, mechanisms of phage adsorption and penetration into host cell. Polish J. Microbiol. 2010, 59, 145-155.

135. Høyland-Kroghsbo, N.M.; Mærkedahl, R.B.; Svenningsen, S.L. A quorum-sensing-induced bacteriophage defense mechanism. mBio 2013, 4. [CrossRef] [PubMed]

136. Seed, K.D.; Yen, M.; Shapiro, B.J.; Hilaire, I.J.; Charles, R.C.; Teng, J.E.; Ivers, L.C.; Boncy, J.; Harris, J.B.; Camilli, A. Evolutionary consequences of intra-patient phage predation on microbial populations. eLife 2014, 3, e03497. [CrossRef] [PubMed]

137. Chatterjee, S.; Rothenberg, E. Interaction of bacteriophage $\lambda$ with Its E. coli receptor, LamB. Viruses 2012, 4, 3162-3178. [CrossRef] [PubMed]

138. Garvey, P.; Hill, C.; Fitzgerald, G.F. The lactococcal plasmid pNP40 encodes a third bacteriophage resistance mechanism, one which affects phage DNA penetration. Appl. Environ. Microbiol. 1996, 62, 676-679. [PubMed]

139. McGrath, S.; Fitzgerald, G.F.; Van Sinderen, D. Identification and characterization of phage-resistance genes in temperate lactococcal bacteriophages. Mol. Microbiol. 2002, 43, 509-520. [CrossRef] [PubMed]

140. Pope, W.H.; Jacobs-Sera, D.; Russel, D.A.; Peebles, C.L.; Al-Atrache, Z.; Alcoser, T.A.; Alexander, L.M.; Alfano, M.B.; Alford, S.T.; Amy, N.E.; et al. Expanding the diversity of mycobacteriophages: Insights into genome architecture and evolution. PLoS ONE 2011, 6. [CrossRef] [PubMed]

141. Kalatzis, P.G.; Rørbo, N.; Castillo, D.; Mauritzen, J.J.; Jørgensen, J.; Kokkari, C.; Zhang, F.; Katharios, P.; Middelboe, M. Stumbling across the same phage: Comparative genomics of widespread temperate phages infecting the fish pathogen Vibrio anguillarum. Viruses 2017, 9. [CrossRef] [PubMed]

142. Shen, X.; Zhang, J.; Xu, J.; Du, P.; Pang, B.; Li, J.; Kan, B. The resistance of Vibrio cholerae O1 El Tor strains to the typing phage 919TP, a member of K139 phage family. Front. Microbiol. 2016, 7, 1-9. [CrossRef] [PubMed]

143. Seed, K.D. Battling Phages: How bacteria defend against viral attack. PLoS Pathog. 2015, 11, 1-5. [CrossRef] [PubMed]

144. Roberts, R.J.; Belfort, M.; Bestor, T.; Bhagwat, A.S.; Bickle, T.A.; Bitinaite, J.; Blumenthal, R.M.; Degtyarev, S.K.; Dryden, D.T.F.; Dybvig, K.; et al. A nomenclature for restriction enzymes, DNA methyltransferases, homing endonucleases and their genes. Nucleic Acids Res. 2003, 31, 1805-1812. [CrossRef] [PubMed]

145. Oliveira, P.H.; Touchon, M.; Rocha, E.P.C. The interplay of restriction-modification systems with mobile genetic elements and their prokaryotic hosts. Nucleic Acids Res. 2014, 42, 10618-10631. [CrossRef] [PubMed]

146. Vasu, K.; Nagaraja, V. Diverse functions of restriction-modification systems in addition to cellular defense. Microbiol. Mol. Biol. Rev. 2013, 77, 53-72. [CrossRef] [PubMed]

147. Matsuzaki, S.; Inoue, T.; Tanaka, S. Evidence for the existence of a restriction-modification system common to several species of the family Vibrionaceae. FEMS Microbiol. Lett. 1992, 94, 191-194. [CrossRef]

148. Murphy, J.; Mahony, J.; Ainsworth, S.; Nauta, A.; van Sinderen, D. Bacteriophage orphan DNA methyltransferases: Insights from their bacterial origin, function, and occurrence. Appl. Environ. Microbiol. 2013, 79, 7547-7555. [CrossRef] [PubMed]

149. Wion, D.; Casadesús, J. N6-methyl-adenine: An epigenetic signal for DNA-protein interactions. Nat. Rev. Microbiol. 2006, 4, 183-192. [CrossRef] [PubMed]

150. Low, D.A.; Weyand, N.J.; Mahan, M.J. Roles of DNA adenine methylation in regulating bacterial gene expression and virulence. Infect. Immun. 2001, 69, 7197-7204. [CrossRef] [PubMed]

151. Portillo, F.G.-D.; Pucciarelli, M.G.; Casadesus, J. DNA adenine methylase mutants of Salmonella typhimurium show defects in protein secretion, cell invasion, and M cell cytotoxicity. Proc. Natl. Acad. Sci. USA 1999, 96, 11578-11583. [CrossRef]

152. Oakey, H.J.; Cullen, B.R.; Owens, L. The complete nucleotide sequence of the Vibrio harveyi bacteriophage VHML. J. Appl. Microbiol. 2002, 93, 1089-1098. [CrossRef] [PubMed] 
153. Loenen, W.A.M.; Dryden, D.T.F.; Raleigh, E.A.; Wilson, G.G.; Murrayy, N.E. Highlights of the DNA cutters: A short history of the restriction enzymes. Nucleic Acids Res. 2014, 42, 3-19. [CrossRef] [PubMed]

154. Luria, S.E. Host-induced modifications of viruses. Cold Spring Harb. Symp. Quant. Biol. 1953, 18, $237-244$. [CrossRef] [PubMed]

155. Balado, M.; Lemos, M.L.; Osorio, C.R. Integrating conjugative elements of the SXT/R391 family from fish-isolated vibrios encode restriction-modification systems that confer resistance to bacteriophages. FEMS Microbiol. Ecol. 2013, 83, 457-467. [CrossRef] [PubMed]

156. Makarova, K.S.; Wolf, Y.I.; Alkhnbashi, O.S.; Costa, F.; Shah, S.A.; Saunders, S.J.; Barrangou, R.; Brouns, S.J.J.; Charpentier, E.; Haft, D.H.; et al. An updated evolutionary classification of CRISPR-Cas systems. Nat. Rev. Microbiol. 2015, 13, 722-736. [CrossRef] [PubMed]

157. Van der Oost, J.; Jore, M.M.; Westra, E.R.; Lundgren, M.; Brouns, S.J.J. CRISPR-based adaptive and heritable immunity in prokaryotes. Trends Biochem. Sci. 2009, 34, 401-407. [CrossRef] [PubMed]

158. Deveau, H.; Barrangou, R.; Garneau, J.E.; Labonté, J.; Fremaux, C.; Boyaval, P.; Romero, D.A.; Horvath, P.; Moineau, S. Phage response to CRISPR-encoded resistance in Streptococcus thermophilus. J. Bacteriol. 2008, 190, 1390-1400. [CrossRef] [PubMed]

159. Andersson, A.F.; Banfield, J.F. Virus population dynamics and acquired virus resistance in natural microbial communities. Science 2008, 320, 1047-1050. [CrossRef] [PubMed]

160. Grissa, I.; Vergnaud, G.; Pourcel, C. CRISPRFinder: A web tool to identify clustered regularly interspace short palindromic repeats. Nucleic Acids Res. 2007, 35, 52-57. [CrossRef] [PubMed]

161. Jørgensen, J. CRISPR-Cas in the Fish Pathogen Vibrio anguillarum. Master's Thesis, University of Copenhagen, Nørregade, Denmark, 2017.

162. Seed, K.D.; Lazinski, D.W.; Calderwood, S.B.; Camilli, A. A bacteriophage encodes its own CRISPR/Cas adaptive response to evade host innate immunity. Nature 2013, 494, 489-491. [CrossRef] [PubMed]

163. Chopin, M.C.; Chopin, A.; Bidnenko, E. Phage abortive infection in lactococci: Variations on a theme. Curr. Opin. Microbiol. 2005, 8, 473-479. [CrossRef] [PubMed]

164. Molineux, I.J. Host-parasite interactions: Recent developments in the genetics of abortive phage infections. New Biol. 1991, 3, 230-236. [PubMed]

165. Snyder, L. Phage-exclusion enzymes: A bonanza of biochemical and cell biology reagents? Mol. Microbiol. 1995, 15, 415-420. [CrossRef] [PubMed]

166. Chowdhury, R.; Biswas, S.K.; Das, J. Abortive replication of choleraphage phi 149 in Vibrio cholerae biotype el tor. J. Virol. 1989, 63, 392-397. [PubMed]

167. Fineran, P.C.; Blower, T.R.; Foulds, I.J.; Humphreys, D.P.; Lilley, K.S.; Salmond, G.P.C. The phage abortive infection system, ToxIN, functions as a protein-RNA toxin-antitoxin pair. Proc. Natl. Acad. Sci. USA 2009, 106, 894-899. [CrossRef] [PubMed]

168. Dy, R.L.; Przybilski, R.; Semeijn, K.; Salmond, G.P.C.; Fineran, P.C. A widespread bacteriophage abortive infection system functions through a Type IV toxin-antitoxin mechanism. Nucleic Acids Res. 2014, 42, 4590-4605. [CrossRef] [PubMed]

169. Iqbal, N.; Guérout, A.M.; Krin, E.; Le Roux, F.; Mazel, D. Comprehensive functional analysis of the 18 Vibrio cholerae N16961 toxin-antitoxin systems substantiates their role in stabilizing the superintegron. J. Bacteriol. 2015, 197, 2150-2159. [CrossRef] [PubMed]

170. Hino, M.; Zhang, J.; Takagi, H.; Miyoshi, T.; Uchiumi, T.; Nakashima, T.; Kakuta, Y.; Kimura, M. Characterization of putative toxin/antitoxin systems in Vibrio parahaemolyticus. J. Appl. Microbiol. 2014, 117, 185-195. [CrossRef] [PubMed]

171. Bohannan, B.J.M.; Kerr, B.; Jessup, C.M.; Hughes, J.B.; Sandvik, G. Trade-offs and coexistence in microbial microcosms. Antonie van Leeuwenhoek, Int. J. Gen. Mol. Microbiol. 2002, 81, 107-115. [CrossRef]

172. Lenski, R.E.; Levin, B.R. Constraints on the coevolution of bacteria and virulent phage: A model, some experiments, and predictions for natural communities. Am. Nat. 1985, 125, 585-602. [CrossRef]

173. Middelboe, M.; Holmfeldt, K.; Riemann, L.; Nybroe, O.; Haaber, J. Bacteriophages drive strain diversification in a marine Flavobacterium: Implications for phage resistance and physiological properties. Environ. Microbiol. 2009, 11, 1971-1982. [CrossRef] [PubMed]

174. Middelboe, M. Bacterial growth rate and marine virus-host dynamics. Microb. Ecol. 2000, 40, 114-124. [CrossRef] [PubMed] 
175. Koskella, B.; Lin, D.M.; Buckling, A.; Thompson, J.N. The costs of evolving resistance in heterogeneous parasite environments. Proc. R. Soc. B Biol. Sci. 2012, 279, 1896-1903. [CrossRef] [PubMed]

176. Castillo, D.; Christiansen, R.H.; Espejo, R.; Middelboe, M. Diversity and geographical distribution of Flavobacterium psychrophilum isolates and their phages: Patterns of susceptibility to phage infection and phage host range. Microb. Ecol. 2014, 67, 748-757. [CrossRef] [PubMed]

177. Marston, M.F.; Pierciey, F.J.; Shepard, A.; Gearin, G.; Qi, J.; Yandava, C.; Schuster, S.C.; Henn, M.R.; Martiny, J.B.H. Rapid diversification of coevolving marine Synechococcus and a virus. Proc. Natl. Acad. Sci. USA 2012, 109, 4544-4549. [CrossRef] [PubMed]

178. Laanto, E.; Bamford, J.K.H.; Laakso, J.; Sundberg, L.R. Phage-driven loss of virulence in a fish pathogenic bacterium. PLoS ONE 2012, 7. [CrossRef] [PubMed]

179. Castillo, D.; Christiansen, R.H.; Dalsgaard, I.; Madsen, L.; Middelboe, M. Bacteriophage resistance mechanisms in the fish pathogen Flavobacterium psychrophilum: Linking genomic mutations to changes in bacterial virulence factors. Appl. Environ. Microbiol. 2015, 81, 1157-1167. [CrossRef] [PubMed]

180. Wendling, C.C.; Piecyk, A.; Refardt, D.; Chibani, C.; Hertel, R.; Liesegang, H.; Bunk, B.; Overmann, J.; Roth, O. Tripartite species interaction: Eukaryotic hosts suffer more from phage susceptible than from phage resistant bacteria. BMC Evol. Biol. 2017, 17, 98. [CrossRef] [PubMed]

181. Rørbo, N.; Rønneseth, A.; Kalatzis, P.G.; Barker Rasmussen, B.; Engell-Sørensen, K.; Kleppen, H.P.; Wergeland, H.I.; Gram, L.; Middelboe, M. Potential of phage therapy in preventing Vibrio anguillarum infections in cod and turbot larvae. Antibiotics 2018. under review.

182. Westra, E.R.; Van houte, S.; Oyesiku-Blakemore, S.; Makin, B.; Broniewski, J.M.; Best, A.; Bondy-Denomy, J.; Davidson, A.; Boots, M.; Buckling, A. Parasite exposure drives selective evolution of constitutive versus inducible defense. Curr. Biol. 2015, 25, 1043-1049. [CrossRef] [PubMed]

183. Tollrian, R.; Harvell, D. The Ecology and Evolution of Inducible Defenses; Princeton University Press: Princeton, NJ, USA, 1999.

184. Iranzo, J.; Lobkovsky, A.E.; Wolf, Y.I.; Koonin, E.V. Evolutionary dynamics of the prokaryotic adaptive immunity system CRISPR-Cas in an explicit ecological context. J. Bacteriol. 2013, 195, 3834-3844. [CrossRef] [PubMed]

185. Lundgren, M. Exploring the ecological function of CRISPR-Cas virus defense. Commun. Integr. Biol. 2016, 9, e1216740. [CrossRef] [PubMed]

186. Stoddard, L.I.; Martiny, J.B.H.; Marston, M.F. Selection and characterization of cyanophage resistance in marine Synechococcus strains. Appl. Environ. Microbiol. 2007, 73, 5516-5522. [CrossRef] [PubMed]

187. Touchon, M.; Moura de Sousa, J.A.; Rocha, E.P. Embracing the enemy: The diversification of microbial gene repertoires by phage-mediated horizontal gene transfer. Curr. Opin. Microbiol. 2017, 38, 66-73. [CrossRef] [PubMed]

188. Davies, E.V.; Winstanley, C.; Fothergill, J.L.; James, C.E. The role of temperate bacteriophages in bacterial infection. FEMS Microbiol. Lett. 2016, 363, 1-10. [CrossRef] [PubMed]

189. Matilla, M.A.; Fang, X.; Salmond, G.P. Viunalikeviruses are environmentally common agents of horizontal gene transfer in pathogens and biocontrol bacteria. ISME J. 2014, 8, 2143-2147. [CrossRef] [PubMed]

190. Billard-Pomares, T.; Fouteau, S.; Jacquet, M.E.; Roche, D.; Barbe, V.; Castellanos, M.; Bouet, J.Y.; Cruveiller, S.; Médigue, C.; Blanco, J.; et al. Characterization of a P1-like bacteriophage carrying an SHV-2 extended-spectrum $\beta$-lactamase from an Escherichia coli strain. Antimicrob. Agents Chemother. 2014, 58, 6550-6557. [CrossRef] [PubMed]

191. Goh, S.; Hussain, H.; Chang, B.J.; Emmett, W.; Riley, T.V.; Mullany, P. Phage $\varphi \mathrm{C} 2$ mediates transduction of Tn 6215, encoding erythromycin resistance, between Clostridium difficile strains. mBio 2013, 4, 1-7. [CrossRef] [PubMed]

192. Iannelli, F.; Santagati, M.; Santoro, F.; Oggioni, M.R.; Stefani, S.; Pozzi, G. Nucleotide sequence of conjugative prophage $\Phi 1207.3$ (formerly Tn1207.3) carrying the $\operatorname{mef}(\mathrm{A}) / \mathrm{msr}(\mathrm{D})$ genes for efflux resistance to macrolides in Streptococcus pyogenes. Front. Microbiol. 2014, 5, 1-7. [CrossRef] [PubMed]

193. Keen, E.C.; Bliskovsky, V.V.; Malagon, F.; Baker, J.D.; Prince, J.S.; Klaus, J.S.; Adhya, S.L. Novel "Superspreader" bacteriophages promote horizontal gene transfer by transformation. mBio 2017, 8, 1-12. [CrossRef] [PubMed]

194. Waldor, M.K.; Mekalanos, J.J. Lysogenic conversion by a filamentous phage encoding cholera toxin. Science 1996, 272, 1910-1914. [CrossRef] [PubMed] 
195. Vidgen, M.; Carson, J.; Higgins, M.; Owens, L. Changes to the phenotypic profile of Vibrio harveyi when infected with the Vibrio harveyi myovirus-like (VHML) bacteriophage. J. Appl. Microbiol. 2006, 100, 481-487. [CrossRef] [PubMed]

196. Paul, J.H. Prophages in marine bacteria: Dangerous molecular time bombs or the key to survival in the seas? ISME J. 2008, 2, 579-589. [CrossRef] [PubMed]

197. Munro, J.; Oakey, J.; Bromage, E.; Owens, L. Experimental bacteriophage-mediated virulence in strains of Vibrio harveyi. Dis. Aquat. Organ. 2003, 54, 187-194. [CrossRef] [PubMed]

198. Busico-Salcedo, N.; Owens, L. Virulence changes to harveyi clade bacteria infected with bacteriophage from Vibrio owensii. Indian J. Virol. 2013, 24, 180-187. [CrossRef] [PubMed]

199. Castillo, D.; Alvise, P.D.; Xu, R.; Zhang, F.; Middelboe, M.; Gram, L. Comparative genome analyses of Vibrio anguillarum strains reveal a link with pathogenicity traits. mSystems 2017, 2, e00001-17. [CrossRef] [PubMed]

200. Reidl, J.; Mekalanos, J.J. Characterization of Vibrio cholerae bacteriophage K139 and use of a novel mini-transposon to identify a phage-encoded virulence factor. Mol. Microbiol. 1995, 18, 685-701. [CrossRef] [PubMed]

201. Karaolis, D.K.R.; Somara, S.; Maneval, D.R.; Johnson, J.A.; Kaper, J.B. A bacteriophage encoding a pathogenicity island, a type-IV pilus and a phage receptor in cholera bacteria. Nature 1999, 399, 375-379. [CrossRef] [PubMed]

202. Nedialkova, L.P.; Sidstedt, M.; Koeppel, M.B.; Spriewald, S.; Ring, D.; Gerlach, R.G.; Bossi, L.; Stecher, B. Temperate phages promote colicin-dependent fitness of Salmonella enterica serovar Typhimurium. Environ. Microbiol. 2016, 18, 1591-1603. [CrossRef] [PubMed]

203. Van Raay, K.; Kerr, B. Toxins go viral: Phage-encoded lysis releases group B colicins. Environ. Microbiol. 2016, 18, 1308-1311. [CrossRef] [PubMed]

204. Bondy-Denomy, J.; Davidson, A.R. When a virus is not a parasite: The beneficial effects of prophages on bacterial fitness. J. Microbiol. 2014, 52, 235-242. [CrossRef] [PubMed]

205. Chen, Y.; Golding, I.; Sawai, S.; Guo, L.; Cox, E.C. Population fitness and the regulation of Escherichia coli genes by bacterial viruses. PLoS Biol. 2005, 3, 1276-1282. [CrossRef] [PubMed]

206. Campbell, A. Conditions for the existence of bacteriophage. Evolution 1961, 15, 153-165. [CrossRef]

(C) 2018 by the authors. Licensee MDPI, Basel, Switzerland. This article is an open access article distributed under the terms and conditions of the Creative Commons Attribution (CC BY) license (http:/ / creativecommons.org/licenses/by/4.0/). 